
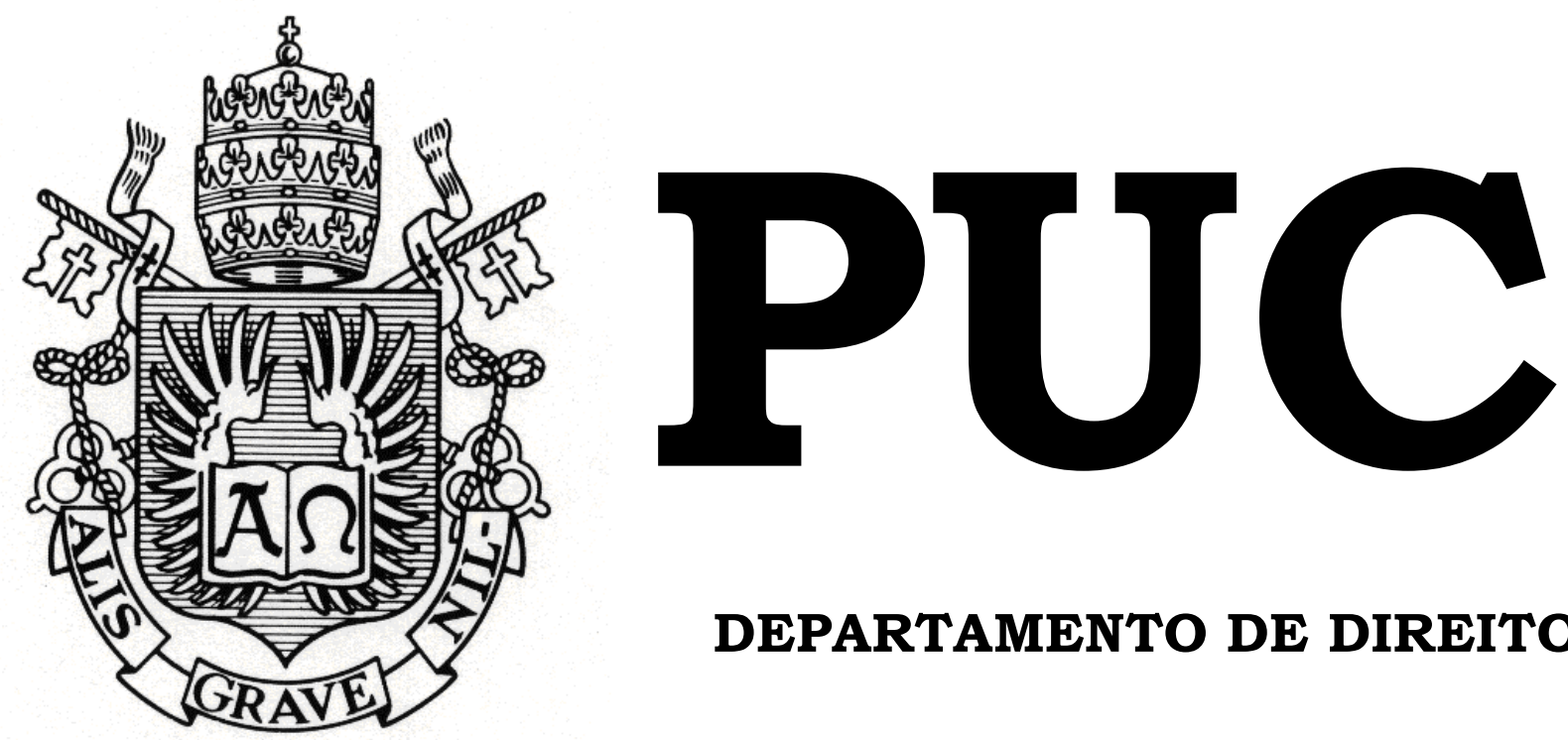

DEPARTAMENTO DE DIREITO

O Devido Processo Legal Substancial e a sua aplicação pelo STF

por

Marcelo Oliveira Basto

ORIENTADOR(A): Professora Victória-Amália

2011.1

PONTIFÍCIA UNIVERSIDADE CATÓLICA DO RIO DE JANEIRO RUA MARQUÊS DE SÃO VICENTE, 225 - CEP 22453-900 RIO DE JANEIRO - BRASIL 


\title{
O Devido Processo Legal \\ Substancial e a sua aplicação pelo STF
}

\author{
Marcelo Oliveira Basto
}

Monografia apresentada ao
Departamento de Direito da
Pontificia Universidade Católica do
Rio de Janeiro (PUC-Rio) para a
obtenção do Título de Bacharel em
Direito.
Orientador(a):
Victória-Amália




\section{DEDICATÓRIA}

A Deus, autor da vida, a Jesus, o Filho de Deus Vivo, a Maria, Mãe de Jesus e minha Senhora, aos meus avós e meus pais, aos meus queridos irmãos, aos amigos, bem como aos homens de boa vontade. De modo especial a Joana, minha esposa, pelo amor e apoio incondicional e a minha filha Bianca, por ela mesma. 


\section{AGRADECIMENTO}

Gostaria de externar minha gratidão a todos que ao longo da minha vida me ensinaram o sentido de ser humano, aqui se incluem homens e mulheres, os mendigos, os pobres em espírito, os presos, as prostitutas, índios, negros, pessoas de todos os credos e nações. De modo especial, aos professores escolares e universitários que vivem e cultivam o ensinar de forma íntegra e séria, bem como aos funcionários. Aos colegas de estudo, com quem aprendi muitas coisas. E à professora Victória-Amália de Sulocki, minha orientadora pela amizade e disponibilidade. 


\section{RESUMO}

O devido processo legal substancial é a vertente material do devido processo legal. Certo é que o devido processo legal no seu surgimento só era compreendido na sua vertente formal. Seja o devido processo legal formal, seja o substancial, o que importa dizer é que se difundiu pelo mundo jurídico ocidental.

O devido processo legal substancial se caracteriza pela aplicação do princípio da proporcionalidade. A ideia de princípio ao lado de outras normas foi sendo usada pelos legisladores e pelos tribunais, bem como foi sendo consolidada pela doutrina, o que deu surgimento a teorias sobre os princípios.

No que toca à proporcionalidade e à razoabilidade, percebe-se que muitas vezes foram e ainda são usados como sinônimos, sem, contudo, o serem. O princípio da proporcionalidade, por sua vez, se desdobra em três elementos, a adequação, a necessidade e a proporcionalidade, os quais devem ser levados em conta para a correta aplicação do instituto.

A aplicação do instituto pelo Judiciário deve ser avaliada desde as possibilidades da ciência, lógica e técnica, passando pela questão da ética e desembocando nas questões e desafios do constitucionalismo contemporâneo. Eis o que foi feito. Valendo-se de quatro decisões escolhidas do STF, fez-se a avaliação das mesmas a partir de todas as questões levantadas anteriormente.

Devido processo legal; Devido processo legal substancial; Razoabilidade; Proporcionalidade; Princípio; Ciência; Ética; Constitucionalismo; Aplicação; Caso concreto 


\section{SUMÁRIO}

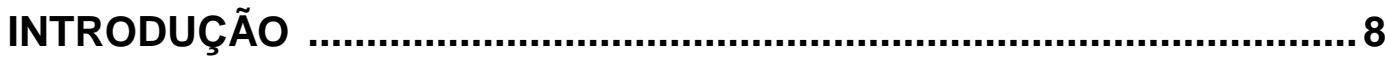

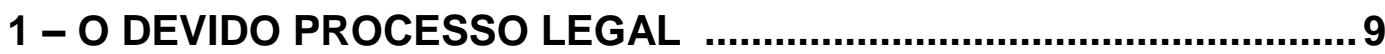

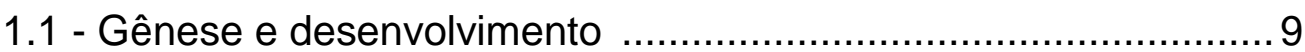

1.2 - Devido Processo Legal Substancia ........................................ 14

2 - DA RAZOABILIDADE E DA PROPORCIONALIDADE.......................19

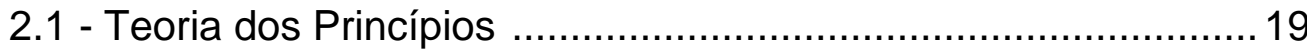

2.2 - Razoabilidade e Proporcionalidade ………………………....26

3 - O DEVIDO PROCESSO LEGAL SUBSTANCIAL E A SUA APLICAÇÃO PELO STF ............................................................... 32

3.1 - Ciência e limites .............................................................. 32

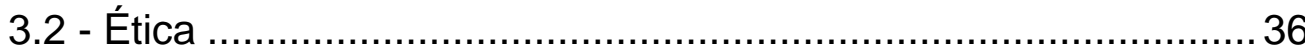

3.3 - Questões e desafios do constitucionalismo contemporâneo .....38

3.4 - O devido processo legal substancial e sua aplicação pelo STF 48

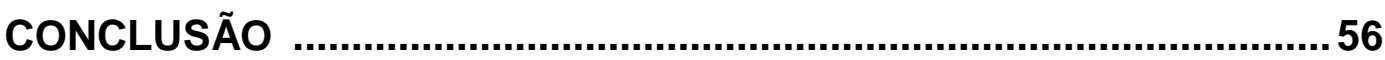

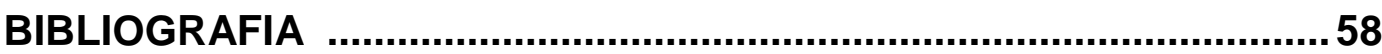




\section{LISTA}

art. - artigo

ed. - edição

EUA - Estados Unidos da América

p. - página

U.S. - United States

v. - versos

STF - Supremo Tribunal Federal

nºs. - números

nº- número

fls. - folhas

e.g. - exemplo de graça

§ - parágrafo 


\section{INTRODUÇÃO}

O presente trabalho tem como objetivo geral o estudo acerca do devido processo legal substancial e como objetivo específico avaliar a sua aplicação pelo Supremo Tribunal Federal.

Para tanto, fez-se necessário expor considerações a respeito da gênese e desenvolvimento do devido processo legal, bem como da sua vertente substancial. Isto foi feito no primeiro capítulo. A exposição levou em conta as normas, a doutrina e a jurisprudência de diversos países, a saber: Inglaterra, Estados Unidos da América e Alemanha.

Dado que o devido processo legal substancial caracteriza-se como a aplicação do princípio da proporcionalidade, fez-se imperioso apresentar a teoria dos princípios. Ainda falou-se da distinção entre razoabilidade e proporcionalidade. Todas estas questões são tratadas no segundo capítulo.

No terceiro e último capítulo, busca-se alcançar o objetivo específico, ou seja, avaliar a aplicação do devido processo legal substancial pelo Supremo Tribunal Federal. No intuito de descobrir quais os critérios e fundamentos das decisões, abordou-se a problemática acerca da ciência e seus limites, a questão da ética e as questões e desafios do constitucionalismo contemporâneo. Por fim, analisou-se a jurisprudência do STF.

Enfim, a pesquisa realizada sobre todos os pontos supracitados permitiu a obtenção de algumas respostas. Destas, foi possível chegar a algumas conclusões sobre o secular instituto do devido processo legal, bem como de outras questões abordadas. 


\section{1 - O DEVIDO PROCESSO LEGAL}

$\mathrm{O}$ instituto que ora pretendemos expor representa, a nosso ver, a sublime garantia dos homens perante o poder soberano. Sublime garantia pelo simples fato de que nada serviria ter direitos fundamentais declarados ou previstos em norma, caso não fosse possível exercê-los ou, na hipótese de violação destes, não houvesse meios de obtê-los. Seria ideal sem real, abstrato sem concreto, teoria sem prática e, mais ainda, mero instrumento para ludibriar consciências humanas. Homens aqui entendido no seu conceito mais largo, ou seja, ser humano. Este vivendo em sociedade organizada sob a égide de um direito. Poder soberano como sendo um poder de direito perante o qual os homens se submetem. Já que um poder soberano arbitrário e sem limites, por óbvio, exclui qualquer possibilidade de existir e aplicar o devido processo legal.

A despeito dos constitucionalistas contemporâneos divergirem em alguns pontos da origem e desenvolvimento do instituto, certo é que há consenso no geral. Sendo assim, por questão de ordem didática no apresentar o tema, escolhemos nos pautar no douto professor Carlos Roberto Siqueira Castro ${ }^{1}$, quem em sede doutrinária foi o primeiro a abordar o instituto no Brasil. Contudo, no intuito de enriquecer o presente estudo, apresentaremos algumas considerações de outros respeitados doutrinadores.

\section{1- Gênese e Desenvolvimento}

O devido processo legal surgiu na Inglaterra, no segundo quartel do século XIII, no medievo, em contexto feudal, com a Magna Carta. O

\footnotetext{
${ }^{1}$ CASTRO, Carlos Roberto Siqueira. O devido processo legal e os princípios da razoabilidade e da proporcionalidade. $4^{\mathrm{a}}$ ed.. Rio de janeiro: Forense, 2006.
} 
sistema feudal compreende na sua estrutura econômico-política e social o vínculo suserano-vassalo, trono e nobreza. Esta relação, como toda e qualquer outra, passível é de conflito ao longo do tempo, também sofreu suas vicissitudes. Com a invasão de Guilherme, o "Conquistador", incentivados foram os privilégios dos barões feudais. A nobreza normanda possuidora e exploradora de terras crescia na acumulação de riqueza e no desejo de poder, o que, consequentemente, os levou a questionar os arbítrios reais. As divergências entre Coroa e nobres encontraram sua regulação formal quando os barões ingleses, sob a liderança do arcebispo de Canterbury, Stephen Langton, conseguiram a aposição do selo real à declaração de direitos por eles elaborada. Tal declaração aceita pelo rei JOÃO "SEM TERRA", entraria e mudaria o rumo da história ocidental, quiçá do mundo, sob o nome de Magna Carta, em 15 de julho de 1215. Sendo tal estatuto marco e símbolo legal para as relações entre o público e o privado. Na ótica de Siqueira Castro:

"nesse estatuto de convivência politica e econômica entre as elites dominantes naquela quadra medieval em que a posse e a exploração da terra constituíam o sinal da própria cidadania embrionária e as fronteiras muito tênues entre o domínio público e o privado".

A cláusula do devido processo legal aparece na Magna Carta, sob a inspiração jusnaturalista que impregnava a ideia de justiça nas instituições jurídicas anglo-saxônicas ${ }^{3}$, no seu art. $39^{4}$, na seguinte expressão: law of the land; per legem terrae(pela lei da terra). ${ }^{5} \mathrm{Na}$ verdade, a expressão due process of law não foi usada na Magna Carta, aparecendo apenas no reinado de Eduardo III, no ano de 1354, numa lei editada pelo Parlamento Inglês

\footnotetext{
${ }^{2}$ Ibid., p. 6.

${ }^{3}$ CASTRO, Carlos Roberto Siqueira. O devido processo legal e os princípios da razoabilidade e da proporcionalidade. $4^{\mathrm{a}}$ ed.. Rio de janeiro: Forense, 2006, p. 6.

${ }^{4}$ Em inglês: "No free man shall be seized or imprisoned, or stripped of his rights or possessions, or outlawed or exiled, or deprived of his standing in any other way, nor will we proceed with force against him, or send others to do so, except by the lawful judgment of his equals or by the law of the land". No original em latim: "Nullus liber homo capiatur vel imprisonetur aut disseisietur de libero tenement suo vel libertatibus, vel liberis consuetudinibus suis, aut utlagetur, aut exuletur, aut aliquo modo destruartur, nec supere o ibimus, nec supere um mittemus, nisi per legale judicium parium suorum, vel per legem terrae". Ibid., p.6-7.

${ }^{5}$ Tradução literária nossa.
} 
(statute of Westminster of the Liberties of London) da pena de um legislador desconhecido, segundo Castro. ${ }^{6}$

Por ora, vale ressaltar o significado das cláusulas constantes deste célebre documento e, de modo particular a do due process of law. O estatuto previa o direito à vida, à liberdade, à propriedade e outros. Todavia, estes direitos fundamentais de nada valeriam caso pudessem ser alijados ou diminuídos pelo soberano ou por algum enviado, a não ser em julgamento legal por seus "iguais" e "pela lei da terra". Sendo assim, estava-se garantindo julgamento e processo conforme a lei. Lei no sentido jurídico atribuído pela common law, ou seja, princípios, costumes, normas e jurisprudência. Aplicado por julgamento (procedimento) legal por seus pares. Se legal, já que estipulada por pacto (Magna Carta) entre nobres e soberano, então devido (dever legal). Devido pelo simples fato de ser "dever".

Importa perceber, também, que o instituto só se aplicava para os barões. Ficava toda a população a margem da garantia. Pois apenas as revoluções liberais estenderiam direitos fundamentais aos burgueses, quando se inicia a chamada democracia liberal de inspiração e índole burguesa. $^{7}$

No entanto, se o mérito da criação da cláusula deve-se aos ingleses, o mesmo não se pode dizer do desenvolvimento. Coube aos colonos da América do Norte, desde os primórdios, recepcioná-la no seu direito, bem como consagrá-la sob a locução "due process of law". ${ }^{8}$

\footnotetext{
${ }^{6}$ Nesse sentido ver CASTRO, Carlos Roberto Siqueira. O devido processo legal e os princípios da razoabilidade e da proporcionalidade. $4^{\mathrm{a}}$ ed.. Rio de janeiro: Forense, 2006, p.7.

${ }^{7}$ Questão política relevante, mas que não pode ser analisada no presente estudo. Haja vista a limitação do tema.

${ }^{8}$ Corwin, citado por Castro, analisa a evolução da garantia do due process of law e de sua passagem do direito inglês para o norte-americano. Ver CASTRO, Carlos Roberto Siqueira. $O$ devido processo legal e os princípios da razoabilidade e da proporcionalidade. $4^{\mathrm{a}}$ ed.. Rio de janeiro: Forense, 2006, p.8.
} 
Várias constituições, bem como as Declarações de Direito9 (Bill of Rights) das treze colônias inglesas, já garantiam o devido processo legal sob a expressão law of the land $^{10}$, mesmo antes da Constituição da federação dos Estados Unidos da América. No que diz respeito à jurisprudência, há muitas decisões ${ }^{11}$ da Suprema Corte norte-americana que entendem as expressões law of the land e due process of law como sinônimo.

Mormente, após termos demonstrado a origem anglo-saxônica e seu desenvolvimento norte-americano, necessário é analisar a diferente carga simbólica que o conceito de devido processo legal adquiriu, bem como o contexto histórico-político e sócio-cultural das Declarações de Direito e Constituições, percebendo a trajetória institucional das revoluções de cada nação e a construção no ideário dos institutos e conceitos.

O Bill of Rights das colônias assumiram, com a criação da federação e sua Constituição, status de norma superior (paramount law), logo oponível a toda e qualquer instituição governamental. Daí ser limitação ao Executivo e, sobretudo, ao Legislativo. Já que nos Estados Unidos da América sempre houve receio do legislativo, haja vista a sufocante legislação metropolitana editada pela Casa de Westminster, em Londres. Enquanto, na Inglaterra, como visto anteriormente, a Magna Carta representou limitações ao monarca. Em termos político, significa dizer que os pioneiros norte-americanos, representados pelos Founding Fathers, ao buscarem sua emancipação política e econômica, lembraram-se dos excessos do Legislativo e trataram de inibi-lo. As revoluções liberais inglesa e francesa, filhas de outro contexto e forma de opressão, intentaram refrear os arbítrios do monarca. Aqui se encontra a razão histórica da

\footnotetext{
${ }^{9}$ É o caso das Declarações dos Direitos: Virgínia, Delaware, Maryland, Carolina do Norte, Vermont, Massachusetts e New Hampshire. Nesse sentido CASTRO, Carlos Roberto Siqueira. $O$ devido processo legal e os princípios da razoabilidade e da proporcionalidade. $4^{\mathrm{a}} \mathrm{ed}$.. Rio de janeiro: Forense, 2006, p. 9-11.

${ }^{10}$ Castro cita interessante estudo de Orlando Bittar, que apoiado em Sir Edward Coke e Cushman, mostra que as expressões per legem terrae, by the law of the land e due process of law foram usadas como sinônimos e, mais ainda, as cartas coloniais insistentemente as usavam indistintamente. Ibid., p. 9.

${ }^{11}$ Como exemplo: caso Davidson v. New Orleans 96 U.S 97 (1877). Ibid., p. 8.
} 
confiança nas Assembleias Legislativas Populares no espírito do povo francês (principalmente) e do inglês. ${ }^{12}$

No tocante às Declarações de Direito da Inglaterra, EUA e França, marcantes são as diferenças essenciais. As inglesas configuram documentos pragmáticos e de propósitos concretos e localizados. ${ }^{13} \mathrm{~A}$ americana é de índole jusnaturalista e compromissos com o individualismo jurídico. ${ }^{14} \mathrm{~A}$ francesa é de nítido caráter burguês, metafísico e universalista. ${ }^{15}$

Coube, no entanto, à novel federação do Norte, inovar e lançar mão de dois mecanismos principais para controlar o Legislativo, quais sejam, o controle judicial da constitucionalidade das leis (judicial review) e o veto presidencial. Foi no judicial review ${ }^{16}$ que o instituto do devido processo legal encontrou guarida e segurança para ser aplicado e crescer.

Questão importante é ressaltar o significado do conceito de legalidade (rule of law), conforme adverte Siqueira Castro: para os americanos, coincide com supremacia da Constituição segundo declarada pelos juízes e tribunais, ao passo que, para os ingleses, significa a vontade do poder legislativo.

Contudo, na Inglaterra, Sir Edward Coke, nos séculos XVI e XVII, no célebre caso Bonham, já tentou se valer do judicial review. É bem verdade que restou vencido no seu voto e na sua defesa da tese de revisão judicial. Acabou até afastado de suas funções pelo rei James I. Sendo discutida a relação de causalidade entre o Dr. Bonham case (1610) e o famoso caso Marbury v. Madison (1803), o qual consagrou o judicial review nos EUA, certo é que os argumentos de Coke foram expressamente usados em decisões nas colônias norte-americanas, bem como

\footnotetext{
${ }^{12}$ A questão nitidamente política da relação de poderes entre Executivo, Legislativo e Judiciário nasce deste contexto histórico.

${ }^{13}$ CASTRO, Carlos Roberto Siqueira. O devido processo legal e os princípios da razoabilidade e da proporcionalidade. $4^{\mathrm{a}}$ ed.. Rio de janeiro: Forense, 2006, p.21.

${ }^{14}$ Ibid., p. 22.

15 Ibid., p. 22.

${ }^{16}$ A análise da legitimidade do judiciário dizer "o que é direito" será estudada adiante na medida em que não fuja do foco do tema. Merece uma verdadeira tese.
} 
influenciaram o espírito norte-americano, já que apareceram publicados no Digest, Abridgements e Reports. ${ }^{17}$

Por fim, vale frisar que o mecanismo de controle jurisdicional da constitucionalidade das leis (judicial review) resulta nos EUA na proeminência do Judiciário. E que a este cabe a função de declarar o que é a lei (what the law is), ou seja, o sentido e o alcance das normas jurídicas. E, mais ainda, que a cláusula do devido processo legal, no pensamento constitucional norte-americano, sempre esteve, como assevera Castro, intimamente associada à própria prerrogativa da revisão judicial e à independência do Poder Judiciário na partilha de competências orgânicas do Estado. $^{18}$

\section{2- Devido Processo Legal Substancial}

A garantia do devido processo legal, como visto, surge na Inglaterra. Contudo, apresentava feição puramente formal, ou seja, mera índole processualista. Na América do Norte, aparece, inicialmente, nas declarações das treze primeiras colônias e, em seguida, na $5^{\mathrm{a}}$ e $14^{\mathrm{a}}$ Emendas da Constituição dos EUA. Também, ainda, na sua vertente formal e restrita à jurisdição penal. É bem verdade que se estenderia à jurisdição civil, bem como, ao seu tempo, chegaria às águas dos procedimentos administrativos na esfera da Administração Pública. Não obstante, caiba todo o mérito aos yankees em alargar a aplicação do devido processo legal formal às esferas civil e administrativa, a melhor contribuição se deve ao gênio criativo em desenvolver o sentido substancial da cláusula. Ou seja, a garantia não apenas ficaria restrita na aplicação dos requisitos formais do processo, mas adentraria no controle do mérito, na substancialidade, no conteúdo. E tal

\footnotetext{
${ }^{17}$ Nesse sentido CASTRO, Carlos Roberto Siqueira. O devido processo legal e os princípios da razoabilidade e da proporcionalidade. $4^{\mathrm{a}}$ ed.. Rio de janeiro: Forense, 2006, p. 16-19.

${ }^{18}$ CASTRO, Carlos Roberto Siqueira. O devido processo legal e os princípios da razoabilidade e da proporcionalidade. $4^{\mathrm{a}}$ ed.. Rio de janeiro: Forense, 2006, p. 24.
} 
criação atribua-se à Suprema Corte dos EUA, que, também, ao formular a teoria do substantive due process haveria, fatalmente, de aplicar a razoabilidade como instrumento de controle dos atos legislativos e administrativos e, consequentemente, de redimensionar a judicial review. ${ }^{19}$ Tudo isso implica no surgimento de inúmeras questões filosóficas, políticas e jurídicas. ${ }^{20}$

No processo penal estadunidense, a cláusula do devido processo legal continha garantias "explícitas” e "implícitas”. As garantias explícitas estavam previstas expressamente no art. $1^{\circ}$, Seção 9 , item 3 da Constituição Norte-Americana, além da $5^{\mathrm{a}}$ e $6^{\mathrm{a}}$ Emendas da Declaração de Direitos (Bill of Rights). As garantias implícitas decorrem da $9^{\mathrm{a}}$ Emenda, pois esta continha previsão expressa de que as decisões judiciais poderiam reconhecer direitos implícitos no sistema constitucional das liberdades públicas. Castro alerta que as garantias implícitas:

"inclui no elenco dos direitos individuais aqueles já titulados pelo povo (retained by the people), o que reverencia a ideia jusnaturalista de direitos "préconstitucionais" e mesmo "pré-estatais" a serem observados pelo Estado, conforme preconizado por Blackstone e Rousseau". ${ }^{21}$

São garantias explícitas: no art. $1^{\circ}$, a proibição de edição de Bill of attainder e de leis retroativas; na $5^{\mathrm{a}}$ Emenda, o direito a julgamento por júri, a proibição de alguém ser julgado duas vezes pelo mesmo fato e a vedação da autoincriminação; $6^{\mathrm{a}}$ Emenda, o direito a um julgamento rápido e público, o direito a ser informado acerca da natureza e causa da acusação, o direito de defesa e ao contraditório e o direito à assistência de advogado. São garantias implícitas constantes da $9^{\mathrm{a}}$ Emenda: o direito de ter seu dia na Corte e a ser ouvido o mais breve possível em audiência judicial, o direito a

\footnotetext{
${ }^{19}$ No que pesem as doutas considerações do ilustre Luís Virgílio Afonso da Silva (p. 29) acerca da origem concreta do princípio da razoabilidade, pensamos, no entanto, ser atribuível à Suprema Corte dos EUA os louros da glória na aplicação do mesmo com o intuito de exercer o controle do mérito e, portanto, da criação do substantive due process. Não se quer, com isso, negar as honras ao tribunal constitucional alemão e à doutrina tedesca pelo aperfeiçoamento dos institutos.

${ }^{20}$ As questões filosóficas, políticas e jurídicas, que exsurgem em torno do tema do devido processo legal substancial, no que pesem sua relevância, merecedoras de verdadeiras teses, serão abordadas superficialmente, sob pena de fugirmos do foco temático.

${ }^{21}$ CASTRO, Carlos Roberto Siqueira. O devido processo legal e os princípios da razoabilidade e da proporcionalidade. $4^{\mathrm{a}}$ ed.. Rio de janeiro: Forense, 2006, p. 31.
} 
contraditar, o de ser notificado por autoridade policial da prerrogativa de permanecer calado e de ser assistido por advogado nomeado pela justiça. ${ }^{22}$ O processo civil também ganharia com o tempo todas as garantias que encerradas na cláusula do due processo of law já eram aplicadas ao processo penal.

Conquanto, tenha o devido processo legal assegurado a efetividade de diversas garantias formais aos processos penal e civil, seria no âmbito da Administração Pública que o instituto se lançaria no mais alto voo, superando o formalismo e assumindo seu caráter substantivo, não sem enfrentar resistências.

Inicialmente, o due process of law foi aplicado aos atos do Poder Público como garantia para observância dos princípios da legalidade e da moralidade administrativa. Sendo de suma importância no controle do poder de polícia (police power).

\begin{abstract}
"Nesse sentido, firmou-se desde cedo o entendimento na jurisprudência norteamericana de que a validade de exercício do police power na esfera jurídica individual depende sempre do prévio conhecimento e da audiência do interessado (notice and hearing), a fim de que o ato do poder público não seja arbitrário ou carente de justificativa". 23
\end{abstract}

Primeiro, como limite procedimental, depois como controle do conteúdo das decisões da Administração Pública. Nesta última função, o devido processo legal se expressa com função de observância da legalidade no que diz respeito ao poder regulamentar de polícia. No tocante ao poder regulamentar, surgiram entre os doutrinadores constitucionalistas norteamericanos as teorias da indelegabilidade e da delegabilidade. Enfim, acabou vencendo a teoria da delegabilidade. Contudo, firmou-se que a delegação deveria exigir limites, sendo necessário, portanto, que o órgão legislativo delegante fixasse standard. O que permitiria ao Judiciário aferir a razoabilidade em cada caso concreto.

\footnotetext{
${ }^{22}$ Nesse sentido CASTRO, Carlos Roberto Siqueira. O devido processo legal e os princípios da razoabilidade e da proporcionalidade. $4^{a}$ ed.. Rio de janeiro: Forense, 2006, p. 29-31.

${ }^{23}$ CASTRO, Carlos Roberto Siqueira. O devido processo legal e os princípios da razoabilidade e da proporcionalidade. $4^{\mathrm{a}}$ ed.. Rio de janeiro: Forense, 2006, p. 36.
} 
Todavia, a concepção substantiva do devido processo legal sofreu vários reveses até ser definitivamente consagrada sua aplicação pela Suprema Corte do EUA. Nos primeiros julgados, esta Corte Maior aplicou a concepção formal do due process of law, chegando expressamente a negar as tentativas de aplicação do sentido substancial. É representativa dessa fase inicial a série de casos intitulada Slaughter-House Cases, do ano de $1873 .^{24}$ Esta visão perdurou por dez anos. No entanto, a Suprema Corte superaria ${ }^{25}$ estas decisões, tão logo a sua composição fosse alterada. Assim, fielmente, interpretando o sentimento jurídico norte-americano que repele a onipotência e a arbitrariedade legislativa. ${ }^{26}$ Esta nova posição se apoiou em antigos precedentes ${ }^{27}$ do período inicial da independência, que valorizavam a ideia de direitos fundamentais de índole jusnaturalista. ${ }^{28} \mathrm{~A}$ partir daí, a Corte Maior vislumbrou na cláusula due process of law a fórmula feita "sob medida" para patrocinar a expansão da judicial review $^{29} \mathrm{e}$, consequentemente, a aplicação da razoabilidade ${ }^{30}$ como instrumento de controle dos atos do Poder Público. Segundo Siqueira Castro: inaugurava-se, aí, a era do "governo dos Juízes". ${ }^{31}$ Trata-se, na

\footnotetext{
${ }^{24}$ Ibid., p. 42.

${ }^{25}$ A superação é uma técnica relevante dentro da própria doutrina e instituto dos precedentes.

${ }^{26}$ CASTRO, Carlos Roberto Siqueira. O devido processo legal e os princípios da razoabilidade e da proporcionalidade. $4^{\mathrm{a}}$ ed.. Rio de janeiro: Forense, 2006, p. 43.

${ }^{27}$ É exemplar, conforme Castro, a opinião do Chefe de Justiça no caso Calder v. Bull do ano de 1798 (3 Dall. 386 (1798), antes até do famoso caso Marbury v. Madison, em 1803, saído da pena de Marshall. Ainda cita outros precedentes: caso Mcculloch v. Maryland, 17 U.S. (4 wheat) 316 (1819); caso Stone v. Farmers Loan Co., 16 U.S. 30 (1866); caso hepbum v. Grisworld, 8 wall 603 (1869); caso Mugler v. Kansas, 123 U.S. 623 (1887); caso Chicago Milwaukee v. Saint Paulv. Minnessota, 134 U.S. 418 (1890); caso Allgeyer v. Louisiana, 165 U.S. 587 (1897). Mas assevera que o leading case na legislação econômica seria o caso Lochner v. New York, 169 U.S. 366 (1898).

${ }^{28}$ CASTRO, Carlos Roberto Siqueira. O devido processo legal e os princípios da razoabilidade e da proporcionalidade. $4^{\mathrm{a}}$ ed.. Rio de janeiro: Forense, 2006, p. 43-44.

${ }^{29} \mathrm{O}$ judicial review contém em si outras tantas questões políticas e jurídicas, a saber: a função orgânica do judiciário (um problema de modelagem institucional) e a ideia de Check and Balance; o fenômeno da mutação constitucional (supõe a concepção de sentimento constitucional); o problema hermenêutico da aplicação do direito e as divergências das correntes "declaratórias" e "construtivistas" (o que, entre nós, deu margem ao surgimento da locução "ativismo judicial"); as questões políticas (o que atualmente, entre nós, vem sendo denominado de "judicialização da política").

${ }^{30}$ A razoabilidade encerra em si profundo e interminável debate filosófico, histórico, sociológico e até antropológico, dado a aplicação da concepção de "standard de justiça". Citemos alguns: Teoria da Justiça e suas vertentes; Ética e suas correntes; Sociedade e tempo; Homem e cultura.

${ }^{31}$ CASTRO, Carlos Roberto Siqueira. O devido processo legal e os princípios da razoabilidade e da proporcionalidade. $4^{\mathrm{a}}$ ed.. Rio de janeiro: Forense, 2006, p. 49.
} 
verdade, na autoafirmação do Judiciário em sua legítima e legal competência no exercício do poder frente ao Legislativo e ao Executivo.

"A dialética do poder e as metafísicas questões do direito público encontram, enfim, no plano institucional, a autoridade dotada de prerrogativa decisória (do final enforcing power) e revestida dos predicados de intérprete derradeiro do sentido da Constituição: O Poder Judiciário". ${ }^{32}$

Vale ressaltar que a aplicação do devido processo legal substancial ficou restrita às questões de liberdades individuais de caráter econômicas. No período de 1930 a 1940, surgiu novo entendimento jurisprudencial, sob a influência da política da New Deal de Roosevelt, no qual a Suprema Corte dos EUA, então, supera a doutrina Lochner. Havendo, assim, um temporário abandono do substantive due process. Certo é que em alguns poucos julgados ainda se pode observar a aplicação da cláusula no seu sentido substantivo. Conquanto, tenha sofrido refrega na década de 30, o instituto alcançaria seu apogeu a partir da década de 60, como garantia máxima dos direitos fundamentais não econômicos. Sendo aplicado em decisões de questões altamente polêmicas, tais como: a utilização de métodos anticoncepcionais e a validade constitucional do aborto.

Ainda, no que toca à aplicação do devido processo legal substancial, necessário é dizer que não há dúvida quanto à influência norte-americana para a difusão do referido instituto pelos demais países do mundo ocidental. Todavia, caberia à doutrina tedesca e ao Tribunal Constitucional Alemão tentativa de aperfeiçoamento do devido processo legal substancial. Já que estes tentam estabelecer criteriosa distinção conceitual e terminológica, como é próprio do espírito (geist) alemão.

\footnotetext{
${ }^{32}$ Ibid., p.49.
} 


\section{2- Da Razoabilidade e da Proporcionalidade}

\section{1- Teoria dos Princípios}

Na tentativa de empreender uma criteriosa análise do princípio da razoabilidade e da proporcionalidade, faz-se necessário apresentar, preliminarmente, algumas questões de suma relevância no estudo do fenômeno do direito, sem as quais restaria sem alicerce a exposição do presente capítulo.

Sendo a razoabilidade e a proporcionalidade tidas como princípios, é mister, esclarecer o que venha a ser princípio. Vale salientar a existência de diversas correntes doutrinárias no mundo do fenômeno jurídico, o que torna a teoria dos princípios um fecundo manancial de polêmicas e divergências, desde a conceituação, passando pelas questões terminológicas e desembocando, ao final, na aplicação judicial. ${ }^{33}$

O vocábulo "princípio" na língua portuguesa assume diversos significados, a saber: começo, início e origem. De fato, ainda está ligado a pontos de vistas (ideológico) do sujeito intérprete, caso este seja um matemático, físico, economista, filósofo, jurista, religioso, político partidário, etc. Sendo assim, pode estar ligado a ideias mais diversas, tais como: postulado, premissa, verdade primeira, dogma, fundamento, essência, dado, fato e verdade universal. Portanto, a tentativa de definir,

\footnotetext{
33 As questões que envolvem o devido processo legal, os princípios e aplicação pelas cortes constitucionais, de modo específico o Supremo Tribunal Federal do Brasil, serão, dentro das possibilidades e dentro dos limites do foco temático, tratadas no último capítulo. Tratam de inúmeras questões acerca do estudo do direito, tais como: Teoria do Direito, Teoria do Estado, Filosofia do Direito, Filosofia Política, Sociologia Jurídica, Antropologia Jurídica, Metodologia Jurídica, Hermenêutica e Constitucionalismo. Nomeadamente, a título de exemplo, são: Jusnaturalismo/Positivismo, Ética, Poder/Decisão e questões políticas, Jurisprudência dos conceitos/interesse/valores/problemas (tópica) e tantas outras que foram magistralmente analisadas por Karl Larenz na sua obra Metodologia da Ciência Jurídica, Hermenêutica e Métodos de Interpretação, Teoria dos Direitos Fundamentais, Judicial Review (controle de constitucionalidade), Mutação Constitucional, Modelagem Institucional, Separação dos Poderes e inúmeros pontos sensíveis que estão na pauta da discussão constitucional contemporânea.
} 
determinar, conceituar rigorosamente a palavra princípio, como qualquer outra, será um esforço infrutífero da linguística e do espírito humano. ${ }^{34}$

No âmbito jurídico, muitas conceituações foram propostas, mas todas apresentavam um defeito capital, como bem salientou o mestre cearense, Paulo Bonavides, “a omissão daquele traço que é qualitativamente o passo mais largo dado pela doutrina contemporânea para a caracterização dos princípios, a saber, o traço de sua normatividade”. ${ }^{35}$ Este mesmo constitucionalista, ainda, apoiado na pesquisa de Ricardo Guastini ${ }^{36}$, quem resumiu os diversos conceitos de princípios, com base na jurisprudência e doutrina, a seis distintos conceitos de princípios (normas com alto grau de generalidade; normas com alto grau de indeterminação; normas de caráter programático; normas de elevada posição na hierarquia das fontes de Direito; normas com função fundamental no sistema jurídico ou político; normas dirigidas aos órgãos de aplicação), ressalta o traço da normatividade. ${ }^{37}$ Todavia, longo foi o itinerário dos "princípios" desde os princípios gerais de direito até sua consagração como princípios constitucionais.

Contemporaneamente, vem sendo analisada, grosso modo, em três fases, a dita juridicidade dos princípios, a saber: jusnaturalista, positivista e pós-positivista. A corrente jusnaturalista entende os princípios como normas ditadas pela reta razão, portanto, de caráter puramente abstrato e universal. Estão, assim, numa dimensão ético-valorativa, assumindo a

\footnotetext{
${ }^{34}$ Nossa posição perante a ideia de ciência se baseia na crítica feita pela mais moderna filosofia da ciência e não mera doxa. Aquela demonstra que a ciência é um saber humano limitado e toda teoria científica pode e será sempre superada. Já que a ideia de ciência concebida, no início da modernidade, encerrava a ideia de progresso e aversão a dogmas imutáveis, apregoando a busca incessante pelo conhecimento. Acabou, no entanto, sendo deturpada por cientistas e intelectuais que não compreenderam o espírito científico (busca e superação contínua). Pois até mesmo nos estágios de conhecimento defendidos por Comte (religião, metafísica e positivo), o estágio da ciência pressupõe progresso, ou seja, inacabado. Se assumirmos dogmas, voltamos à religião. Sendo assim, a ciência acaba se tornando o mais novo discurso religioso disfarçado e fundamentalista, instrumento de poder de alguns, completa negação dos seus ideais de origem.

${ }^{35}$ BONAVIDES, Paulo. Curso de Direito Constitucional, $20^{\mathrm{a}}$ ed.. São Paulo: Malheiros, 2007, p. 257.

${ }^{36}$ Riccardo Guastini, Dalle Fonti alle Norme, p. 112 apud BONAVIDES, Paulo. Curso de Direito Constitucional, 20 ${ }^{\mathrm{a}}$ ed.. São Paulo: Malheiros, 2007, p. 257.

${ }^{37} \mathrm{O}$ mestre cearense, neste passo, sustenta a posição dos normativistas.
} 
feição de axiomas jurídicos, verdadeiros postulados de justiça. Fica claro, consequentemente, que o ideal de justiça é a preocupação essencial dos jusnaturalistas. Daí sustentarem “a insuficiência dos princípios extraídos do próprio ordenamento jurídico positivo, para preencher as lacunas da lei e a necessidade consequente de recorrer aos do Direito Natural". ${ }^{38}$ Ou seja, os princípios gerais de direito não necessariamente precisam estar normatizados ou serem extraídos de normas positivas. A corrente positivista, basicamente, entende que os princípios gerais de direito devem estar normatizados. Sendo assim, não haveria que se falar, no mundo jurídico, em princípios fora do direito positivo. Numa palavra, os princípios são normas positivas. Todavia, nesta fase, os princípios ingressam no ordenamento via códigos, com a restrita função de ser fonte normativa subsidiária. Ou seja, não podem se sobrepor à lei, ou melhor, às outras normas, tendo, logo, a função de suprimir as lacunas do ordenamento. Enfim, a atual fase pós-positivista, inaugurada no século XX com a promulgação das novas Constituições, onde os princípios foram positivados constitucionalmente, migrando dos códigos às constituições contemporâneas, da esfera jusprivatista para a juspublicista, põe os princípios constitucionais como pedra fundamental do sistema jurídico. O fenômeno pós-positivista e o constitucionalismo contemporâneo se alimentaram e ainda se alimentam de diversas reflexões doutrinárias e da criação jurisprudencial, bem como verdadeira é a recíproca, estando, consequentemente, em processo hodierno de construção.

Passemos, então, a uma breve exposição, no tocante ao nosso objeto de estudo, a teoria dos princípios, de algumas teses marcantes ${ }^{39}$ de doutrinadores. Segundo Bonavides ${ }^{40}$, Boulanger fora o primeiro jurista a distinguir regras e princípios, bem como fez estudo analisando e

\footnotetext{
${ }^{38}$ BONAVIDES, Paulo. Curso de Direito Constitucional, $20^{\mathrm{a}}$ ed.. São Paulo: Malheiros, 2007, p.262.

${ }^{39}$ A nosso sentir. O que não pretende, com isso, menosprezar outros doutrinadores.

${ }^{40}$ Nesse sentido BONAVIDES, Paulo. Curso de Direito Constitucional, $20^{a}$ ed.. São Paulo: Malheiros, 2007, p. 266.
} 
classificando os tipos de princípios, mas não investigou a formação e a função dos mesmos. Posteriormente, Esser aprofundou a obra de Boulanger. Além da distinção, o que marcou a obra de Boulanger foi a sua tentativa de afirmar a positivação dos princípios. Outros grandes precursores foram Gutzwiller e Goldschmidt. O primeiro, afirmava que Direito sem princípios nunca houve verdadeiramente ${ }^{41}$, o segundo, defendia que princípio é apenas princípio de interpretação. O italiano Emilio Betti, segundo Bonavides, tinha posição dúbia acerca da normatividade dos princípios. Afirmava que princípio não pode se constituir numa norma acabada e formulada, já que tem um excesso de conteúdo deontológico, no entanto, também sustentava a exigência de que todo preceito jurídico deve ser formulado em termos normativos. Larenz e Grabitz concebem os princípios como princípios "abertos". Grabitz chega a afirmar que os princípios estão no Direito Positivo, mas não são normas. Crisafulli, por sua vez, defende que um princípio pode estar explícito ou implícito num ordenamento, no entanto, seja como for, é norma. Todos estes juristas contribuíram sobremaneira para a fundamentação e aplicação dos princípios, ainda que estivessem de uma forma ou de outra ligados à velha hermenêutica consagrada pelo jusprivatismo.

A grande virada ocorreu com a mudança de perspectiva surgida com o juspublicismo pós-positivista. Uma nova visão metodológica e hermenêutica surgiu, buscando construir e rever o Direito sob nova dimensão e ótica, o que, consequentemente, trouxe à tona inúmeras questões polêmicas no estudo do fenômeno jurídico, que, supostamente, estavam pacificadas. São simbólicas questões como: princípios, direitos fundamentais, interpretação, aplicação e tantas outras. ${ }^{42}$

No desenvolvimento da teoria dos princípios em perspectiva juspublicista se destacaram, como precursores, juristas renomados como

\footnotetext{
${ }^{41}$ Nesse sentido BONAVIDES, Paulo. Curso de Direito Constitucional, 20ª ed.. São Paulo: Malheiros, 2007, p. 268.

${ }^{42}$ Neste capítulo, exporemos, na medida do necessário ao desenvolvimento do objeto temático, acerca dos princípios. Outras questões serão tratadas no último capítulo.
} 
Müller e Dworkin. O primeiro, na Alemanha, desenvolveu uma teoria estruturante de Direito de índole normativista. Em suma, buscava superar o formalismo normativista de Kelsen, para tanto se utiliza de vias conceituais dentro de uma concepção material. Dworkin ${ }^{43}$, por sua vez, ataca a dualidade Direito/Moral que o positivismo preconiza e, de modo especial, a filosofia jurídica de $\mathrm{Hart}^{44}$, mestre de Oxford, que levou ao extremo a dicotomia positivista. O mestre de Harvard afirma a conexidade entre Direito e Moral. Sua doutrina teve consequência direta na teoria dos princípios, já que decorre desta uma nova compreensão acerca da natureza dos princípios. Os princípios são definitivamente normas e, mais ainda, são normas-valores positivadas nas Constituições. Portanto, possuidoras do mais alto peso no sistema jurídico. Numa palavra, norma é gênero, do qual princípios e regras são espécies. Estava, assim, conceituada, definida e consolidada a teoria dos princípios na perspectiva do juspublicismo póspositivista.

Para Dworkin ${ }^{45}$, as regras devem ser aplicadas à maneira tudo ou nada (an all or nothing). Ocorrendo um fato previsto na regra, esta deverá incidir no caso, sendo a consequência aquela também prevista na regra, pois a mesma está plenamente válida no sistema. Ou seja, as regras operam na dimensão da validade. Caso ocorra um fato e surja um conflito entre duas regras possíveis de aplicação ao mesmo, como se deve solucionar? O mestre de Harvard, afirma, então, que uma delas não é válida. Sendo necessário decidir qual delas é válida. Tal decisão é exterior às próprias regras. Escolhida uma regra como válida, consequentemente será a outra afastada do caso e, mais ainda, dado a dimensão de validade, a regra passará a ser inválida para qualquer outro fato. Ou seja, não mais pertence ao ordenamento jurídico. Pois, afirma ainda Dworkin, que as regras

\footnotetext{
${ }^{43}$ DWORKIN, Ronald. Levando o direito a sério. $3^{\mathrm{a}}$ ed. São Paulo: Martins Fontes, 2010.

${ }^{44}$ HART, H. L. A.. O conceito de Direito. São Paulo: Martins Fontes, 2010.

${ }^{45}$ DWORKIN, Ronald. Levando o direito a sério. $3^{\text {a }}$ ed. São Paulo: Martins Fontes, 2010.
} 
preveem um fato e prescrevem um resultado (consequência; sanção) e se ocorrido o fato chegasse a um resultado diferente, tal regra não regrou, portanto deve ser abandonada ou reformada.

Os princípios, a seu turno, não operam à maneira tudo ou nada, ou seja, na dimensão de validade, mas sim na dimensão de peso (valor). Portanto, é da natureza mesma dos princípios poderem ser sopesados. Imaginemos que diante da busca da solução de um caso, dois ou mais princípios possam oferecer resultados diversos. O que fazer? Deve-se escolher um princípio a ser aplicado ao caso. Todavia, o princípio ou os demais princípios que não prevaleceram, permanecem intactos no ordenamento jurídico. Dado que princípios não prescrevem um resultado particular. Todavia, resta responder a uma questão crucial, a saber: como escolher? Neste ponto parece-nos que Dworkin não obteve resposta criteriosa. Limita-se a falar em relevância e peso dos princípios, sem, contudo, apresentar o modus de sopesar. Coube ao notável jurista alemão Robert Alexy aprofundar os estudos da teoria dos princípios.

Alexy $^{46}$ parte dos estudos da teoria material dos direitos fundamentais, mais especificamente, da teoria normativo-material, e chega à sua distinção entre regras e princípios. Ele conclui que estes são normas obtidas a partir de expressões deônticas fundamentais, tais como: mandamento, permissão e proibição. Afirma, ainda, que princípios e regras são fundamentos para juízos concretos de dever. Estuda os diversos critérios propostos por juristas para a distinção entre regras e princípios:

“o da 'determinabilidade dos casos de aplicação' (Esser), o da origem, o da diferenciação entre normas 'criadas'(geschaffene) e normas 'medradas' ou 'crescidas' (gewachsene Normen), referidas por Schuman e Eckhoff, o da explicitação do teor de valoração (Canaris), o da relação com a ideia de Direito (Larenz) ou com a lei suprema do Direito (Bezug zu einem obersten Rechtsgezetz), segundo H. J. Wolff, e, finalmente, o da importância que têm para a ordem jurídica (entre outros, Peczenik e Ziembinski)". ${ }^{47}$

\footnotetext{
${ }^{46}$ ALEXY, Robert. Teoria da norma jurídica. São Paulo: Martins Fontes, 2010.

${ }^{47}$ BONAVIDES, Paulo. Curso de Direito Constitucional, $20^{\mathrm{a}}$ ed.. São Paulo: Malheiros, 2007, p. 278.
} 
Alexy conclui que o mais comum é o da generalidade. Sob este critério tem-se que princípios são normas com alto grau de generalidade, enquanto regras são normas de baixo grau de generalidade.

Da análise dos distintos critérios, Alexy conclui haver três possíveis teses para distinguir regras e princípios. Uma delas é bastante ceticista, já que afirma que nenhum dos critérios de per si seja suficiente para fundamentar a distinção. Outra, apesar de aceitar que as normas são gêneros e regras e princípios são espécies, baseia a distinção numa gradualidade, ou seja, o critério maior de distinção seria o da generalidade. A última das três teses, a defendida por Alexy, propugna que a distinção não se faz apenas por grau, mas também por qualidade. Na ótica deste critério, os princípios seriam "mandamentos de otimização" (Optimierungsgebot). ${ }^{48}$ Tais normas de otimização na sua aplicação "não dependem apenas de possibilidades fáticas, senão também jurídicas". ${ }^{49}$ As regras são normas a serem aplicadas ou não, a depender de sua validade. Se válida, seja aplicada na medida exata do seu comando. Assim, a regra contém uma aplicação limitada à sua possibilidade fática e jurídica que decorre do próprio texto da mesma. Os princípios, por sua vez, na sua possibilidade fática e jurídica não contêm esta limitação, pois seu comando não determina solução fechada. Eis, segundo Alexy, a distinção de qualitativa.

Para Alexy, o conflito de regras e a colisão de princípios se distinguem pelo modo de solução. Os conflitos de regras se resolvem na dimensão da validade. Ou seja, havendo conflito será uma regra tida por válida e a outra será declarada nula ou introduzir-se-á uma cláusula de exceção numa das regras. No caso de colisão de princípios, a solução se acha na dimensão de peso. Havendo colisão deverá prevalecer o princípio de maior peso. Portanto, não há que se falar em sopesamento em abstrato, mas no caso concreto. Pois, sob as circunstâncias determinadas de um caso

\footnotetext{
${ }^{48}$ Nesse sentido BONAVIDES, Paulo. Curso de Direito Constitucional, 20ª ed.. São Paulo: Malheiros, 2007, p. 278.

${ }^{49}$ BONAVIDES, Paulo. Curso de Direito Constitucional, $20^{\mathrm{a}}$ ed.. São Paulo: Malheiros, 2007, p. 279.
} 
concreto poderá um princípio ter maior peso que outro e prevalecer. Já em outro caso concreto e sob outras circunstâncias poderão os mesmos princípios colidentes ter pesos diferentes, preponderando o princípio que noutro caso teve menor peso, mas neste novo caso concreto apresenta maior peso.

Enfim, o próprio Alexy levanta objeções ao seu conceito de princípio. Uma que afirma há existência de princípios extremamente fracos, ou seja, no caso de colisão nunca prevalecem. Daí a colisão resolver-se-ia por declaração de invalidade. Outra seria a ocorrência de princípios absolutos. O que levaria a se falar em princípios sem limites jurídicos, que em caso de colisão venceria a priori, em abstrato. Assim, seria uma contradição em termos, pois não se poderia sopesar uma colisão de um princípio absoluto. Sem falar na possibilidade insolúvel da colisão de dois princípios absolutos. A última objeção está no próprio conceito de princípio, que é vago, o que dá abertura à defesa de todo e qualquer interesse possível. ${ }^{50}$

\section{2 - Razoabilidade e Proporcionalidade}

Neste ponto, pretende-se expor as questões em torno da razoabilidade e da proporcionalidade numa dimensão analítico-conceitual, dado que no último capítulo buscar-se-á apresentar as mesmas numa perspectiva empírica. ${ }^{51}$

No item anterior, expusemos uma breve síntese a respeito de uma pretensa teoria dos princípios, bem como concluímos que a teoria de Alexy parece ser, até o atual estágio dos estudos jurídicos, a mais desenvolvida. Percebeu-se também a dificuldade de definição do termo princípio, devido à

\footnotetext{
${ }^{50}$ As questões da limitação dos conceitos e da própria ciência serão alvo de exposição no último capítulo.

${ }^{51}$ Na dimensão empírica, ter-se-á como objeto específico a jurisprudência do STF. Todavia, por vezes, será necessário recorrer à jurisprudência alienígena.
} 
sua forte carga semântica (plurivocidade). Sendo assim, elencamos, a título de exemplo, algumas definições de notáveis juristas. Com isso, devemos abordar, inicialmente, a questão de saber se razoabilidade e proporcionalidade são princípios. Na teoria de Alexy, segundo Luís Virgílio Afonso da Silva ${ }^{52}$, "o chamado princípio da proporcionalidade não pode ser considerado um princípio" ${ }^{53}$ Para Luís Virgílio, a distinção entre regras e princípios de Alexy se baseia nos critérios de estrutura e aplicação da norma e não nos critérios de generalidade e especialidade, tais como pensa expressiva parcela de juristas brasileiros (e.g.: Bonavides e Humberto Ávila). "Regras expressam deveres definitivos e são aplicadas por meio de subsunção. Princípios expressam deveres prima facie, cujo conteúdo definitivo somente é fixado após sopesamento com princípios colidentes". ${ }^{54}$ Logo, o corriqueiramente chamado princípio da proporcionalidade não é princípio, pois na sua aplicação tem um conteúdo definitivo, ou seja, tem um dever definitivo, sopesar princípios colidentes. Portanto, seria, a rigor, na teoria de Alexy, uma regra. Devendo, assim, ser aplicada por meio de subsunção. Porém, Virgílio mesmo percebe que na prática jurídica brasileira já se consagrou o uso do termo princípio da proporcionalidade, talvez com intuito de dar a devida importância ao conceito.

Questão assaz relevante é perceber como se dá o uso dos termos razoabilidade e proporcionalidade na doutrina e na jurisprudência. Pode-se afirmar com toda segurança haver a utilização dos termos como sinônimos. Contudo, como assevera Virgílio, estes não são sinônimos. Alega, para tanto, haver diferença de origem e estrutura. Quanto à questão da origem, preferimos seguir o que já diziam os romanos de fontibus non disputandum, ou seja, sobre as origens não se discute. Todavia, como expusemos a opinião de Siqueira Castro, vale sintetizar a opinião diversa de Virgílio. Diz

\footnotetext{
${ }^{52}$ SILVA, Luís Virgílio Afonso da. "O proporcional e o razoável”. Revista dos Tribunais. V. 798, p. 23-50, abril de 2002.

${ }_{54}^{3}$ Ibid., p. 25.

${ }^{54}$ Ibid., p.25.
} 
este que, na Inglaterra, o termo proporcionalidade não aparece na Magna Carta e, mais ainda, que antes do Human Rights Act de 1988 o termo não era de interesse da doutrina inglesa, sendo praticamente desconhecido. Questiona ainda o termo razoabilidade, ao afirmar que este não constava na Magna Carta, mas sim o termo irrazoabilidade. ${ }^{55} \mathrm{E}$ mesmo este último só teria sua origem concreta e na forma como se aplica na Inglaterra na decisão Associated Provincial Picture House Ltd. v. Wednesburry Corporation de 1948. "Se uma decisão (...) é de tal forma irrazoável, que nenhuma autoridade razoável a tomaria, então pode a Corte intervir". ${ }^{56}$ Esse teste da irrrazoabilidade ficou conhecido como teste Wednesburry. Note-se que o teste em questão tem uma estrutura simples, qual seja, pode a Corte rejeitar atos excepcionalmente irrazoáveis. Ainda, segundo Virgílio, o termo proporcionalidade e razoabilidade também são usados indiscriminadamente na jurisprudência da Suprema Corte dos EUA com base no substantive due process. Esta imprecisão não é privilégio da Corte Maior norte-americana, o Supremo Tribunal Federal Brasileiro assim também o faz. Por fim, conclui a análise da origem e estrutura dos referidos termos, atribuindo a criação da regra da proporcionalidade ao Tribunal Constitucional alemão. Este teria dado estrutura racionalmente definida à regra da proporcionalidade. Seriam seus elementos, numa ordem prédefinida para análise da aplicação da regra, a adequação, a necessidade e proporcionalidade em sentido estrito.

Feita a distinção de termos entre razoabilidade e proporcionalidade, passemos à questão terminológica do próprio termo proporcionalidade. A tormenta está no uso de outros termos e conceito para designar a proporcionalidade. Segundo Bonavides, na Alemanha, grassava o uso de muitos termos para a proporcionalidade, tanto na doutrina como na Corte

\footnotetext{
${ }^{55}$ A nosso ver, o fato do termo razoabilidade em si não constar na Magna Carta é apenas uma sutileza, já que do termo irrazoabilidade a contrário senso se chega a razoabilidade. O problema estaria na estrutura, se seguirmos o raciocínio de Virgílio.

56 SILVA, Luís Virgílio Afonso da. "O proporcional e o razoável". Revista dos Tribunais. V. 798, p. 23-50, abril de 2002, p. 29.
} 
constitucional, o que gerava tremenda ambiguidade. Citando Hans Schneider, jurista alemão que compilou as decisões da Corte alemã e elencou as qualificações usadas por esta, Bonavides ${ }^{57}$ as expõe: excessivo (übermässig); inadequado (unangemessen), racional (vernünftig); materialmente justo e legítimo (sachgerecht und vertretbar); necessário (erforderlich); indispensável (unerlässlich); e absolutamente necessário (unbedingt notwendig). Contra esta confusão e total falta de clareza se insurgiram os doutrinadores alemães. Rupprecht von Krauss tentou sistematizar o princípio da proporcionalidade, mas acabou afirmando que “a expressão princípio da proporcionalidade (Grundsatz der Verhältnismässigkeit) significava tão-somente princípio da necessidade (Grundsatz der Erforderlichkeit). Seria Lerche o consolidador da distinção entre proporcionalidade e necessidade, pondo ambas sob o conceito de proibição de excesso (Übermassverbot). Já a Corte alemã reuniu dentro do conteúdo de proibição de excesso (Übermassverbot) os elementos da adequação (Geeignetheit), da necessidade (Erforderlichkeit), da proporcionalidade em sentido estrito (Verhältnismässigkeit). Contudo, até os elementos sofrem com a ambiguidade terminológica, como assevera Bonavides na esteira de Hirschberg, que levantou diversos sinônimos usados pelo Tribunal Maior alemão para a adequação, necessidade e proporcionalidade em sentido estrito. Se, no entanto, há vacilo no uso dos termos, pode-se afirmar com alguma segurança que o princípio da proporcionalidade contém no seu conceito a ideia, a finalidade de controle contra os excessos do poder estatal. Por fim, Virgílio traz à baila o mais novo entendimento de proporcionalidade. Se antes se falava em proibição de excesso (Übermassverbot), começou-se recentemente a falar em proibição de insuficiência (Untermassverbot). Ou como gosta Canotilho, proibição por defeito. ${ }^{58}$

\footnotetext{
${ }^{57}$ BONAVIDES, Paulo. Curso de Direito Constitucional, $20^{\mathrm{a}}$ ed.. São Paulo: Malheiros, 2007, p. 404.

${ }^{58}$ Nesse sentido SILVA, Luís Virgílio Afonso da. "O proporcional e o razoável”. Revista dos Tribunais. V. 798, p. 23-50, abril de 2002, p. 27.
} 
Inicialmente, vale ressaltar que a aplicação da regra de proporcionalidade e seus elementos devem obedecer a uma ordem prédefinida na análise dos elementos, subregras ou subprincípios. Começa-se pela adequação, em seguida, avalia-se a necessidade e, por derradeiro, analisa-se a proporcionalidade em sentido estrito. Todavia, deve-se atentar ainda que os elementos também guardam uma relação entre si de subsiariedade. Ou seja, não será sempre necessário avaliar todos os elementos.

\footnotetext{
"Com subsiariedade quer-se dizer que a análise da necessidade só é exigível se, e somente se, o caso já não tiver sido resolvido com a análise da adequação; e a análise da proporcionalidade em sentido estrito só é imprescindível, se o problema já não tiver sido solucionado com as análises da adequação e da necessidade". 59
}

Virgílio ainda chama a atenção de que há três tendências quanto ao número de subregras. Uma divide a proporcionalidade em três subprincípios, a saber: adequação, necessidade e proporcionalidade em sentido estrito. Outra fala em dois elementos: adequação e necessidade. E há uma terceira que acrescenta aos três tradicionais elementos um novo, qual seja, legitimidade dos fins que a medida questionada pretende atingir. Esta última é defendida pelos que estudam a aplicação da regra da proporcionalidade pela Corte Europeia de Direitos Humanos.

Quanto ao elemento adequação, muitos doutrinadores afirmam ser o uso da "medida certa para alcançar um fim". Virgílio, contudo, insurge-se contra tal afirmação ao criticar a tradução feita por Gilmar Ferreira Mendes de uma decisão da Corte Maior alemã. Já que esta usa o verbo fördern, que quer dizer fomentar e não alcançar, como traduz Mendes. Portanto, basta que a medida fomente um resultado, mesmo que este não seja alcançado.

\footnotetext{
${ }^{59}$ SILVA, Luís Virgílio Afonso da. "O proporcional e o razoável”. Revista dos Tribunais. V. 798, p. 23-50, abril de 2002, p. 35 .
} 
$\mathrm{O}$ elemento necessidade se refere à medida ou ato estatal que possa limitar um direito fundamental no que diz respeito a sua necessária utilização para o fim a que se almeja. Bonavides ${ }^{60}$ colhe duas felizes expressões que bem explica este subprincípio, uma de Xavier Philippe, "de dois males, faz mister escolher o menor", outra de Maunz/Duerig, "princípio da escolha do meio mais suave". Note-se que há uma diferença no exame de adequação e de necessidade. Na adequação, a avaliação da medida (meio) faz-se em termos absolutos. Na necessidade, o exame é comparativo. ${ }^{61}$

Por fim, o subprincípio da proporcionalidade em sentido estrito que pode numa palavra ser definido, sopesamento. Virgílio afirma que o exame da proporcionalidade em sentido estrito

"consiste em um sopesamento entre a intensidade da restrição ao direito fundamental atingido e a importância da realização do direito fundamental que com ele colide e que fundamenta a adoção da medida restritiva". ${ }^{62}$

O subprincípio da proporcionalidade em sentido estrito pode ser definido numa palavra, sopesamento.

\footnotetext{
${ }^{60}$ BONAVIDES, Paulo. Curso de Direito Constitucional, $20^{\mathrm{a}}$ ed.. São Paulo: Malheiros, 2007, p. 397.

${ }^{61}$ Nesse sentido SILVA, Luís Virgílio Afonso da. "O proporcional e o razoável”. Revista dos Tribunais. V. 798, p. 23-50, abril de 2002, p. 39.

${ }^{62}$ SILVA, Luís Virgílio Afonso da. "O proporcional e o razoável". Revista dos Tribunais. V. 798, p. 23-50, abril de 2002, p. 40.
} 


\section{3 - O DEVIDO PROCESSO LEGAL SUBSTANCIAL E A SUA APLICAÇÃO PELO STF}

\section{1 - Ciência e limites}

Antes de iniciarmos a análise da jurisprudência do STF, é mister, por questão de ordem lógica, expor e avaliar pressupostos, perspectivas, paradigmas, modelos e métodos existentes da ciência. Pois não se pode construir uma casa começando pelo telhado. Antes se devem pôr as fundações, depois os pilares, as vigas mestras, paredes divisórias e, por fim, o telhado. Assim também se exige das pesquisas e estudos científicos.

$\mathrm{Na}$ exposição dos capítulos anteriores, algumas questões foram levantadas, mas não explicadas. Estas são, na verdade, pontos fundamentais para uma pretensa pesquisa científica, bem como para chegar ao fim do nosso itinerário. Portanto, buscaremos esclarecer, na medida do possível, as mesmas. Nominadamente, abordaremos a Ciência e seus limites, passando pela reflexão acerca das ditas ciências humanas e seus problemas, onde falaremos brevemente sobre antropologia, sociologia, política e ética. Com isso, podemos indagar a ideia de Direito. Ou seja, o Direito é uma ciência? Em que moldes? A partir de então se deve apresentar a metodologia jurídica. Ou melhor, realizar um breve estudo das correntes e jurisprudências do método no direito, dado que da escolha de uma determinada postura se condiciona o objeto. E, mais ainda, se adere a uma perspectiva hermenêutica. Sendo assim, necessária será uma explanação sucinta sobre hermenêutica jurídica. Por derradeiro, alcançamos a teoria dos direitos fundamentais, bem como sua interpretação e aplicação, que é de fundamental importância para o tema em questão, já que o devido processo legal é um direito fundamental expressamente previsto na Constituição da República Federativa do Brasil de 1988. Será, portanto, a partir das conclusões obtidas nestas questões preliminares que se procederá ao estudo 
das decisões do Supremo Tribunal Federal no tocante ao devido processo legal substancial.

A primeira indagação fundamental é: O que é ciência? Importa saber que o homem sempre buscou saber, conhecer e dominar. Seja movido pelo medo, pela admiração, seja pelo instinto, por paixão ou pelo poder, ele o fez. O ponto está em estipular quando o conhecimento é dito científico. A resposta a essa questão é espinhosa e inflamadora dos ânimos. O conhecimento, pode-se dizer, passa por uma medida em escala. Alguns põem o conhecimento científico a partir de um determinado ponto da escala, outros em pontos diferentes. E assim, eis a querela. Fala-se em mito, religião, metafísica e ciência. ${ }^{63}$ Tudo depende do ponto de vista do sujeito que determina. Sujeito este filho de seu tempo, de sua cultura, da sociedade a qual faz parte. Estas circunstâncias irão em certa medida condicioná-lo. Terá ideias, crenças, valores, sentimentos e preconceitos, mas também tem vontade e escolha. Estará sempre escravo do ambiente, da cultura? É de todo livre nas suas escolhas? Tais questões são verdadeiras aporias presentes no pensar dos homens desde os primórdios, haja vista que o homem pensa, e se pensa, tem dúvidas e perguntas a serem respondidas. Sendo assim, é da condição humana o pensar, a busca pelo conhecimento, as perguntas infinitas e incessantes. Como dizia Blaise Pascal, no homem há grandeza e miséria. ${ }^{64}$ A partir desse dado antropológico devemos pensar o homem e a ciência feita pelo mesmo.

Longo vem sendo o itinerário humano na busca pelo conhecimento. Todos os povos ansiavam pelo conhecimento, desde os homens das cavernas, passando pelos povos do antigo oriente ao ocidente gregoromano. Nesta última cultura diz ter nascido a filosofia, o que, na verdade, é uma afirmação etnocêntrica ocidental. Tales de Mileto falava em arché (princípio). Heráclito de Éfeso respondeu suas perguntas com o logos e o dinamismo, o relativismo, ao dizer pantha rei( tudo se move; tudo escorre;

\footnotetext{
${ }^{63}$ COMTE, Augusto. Curso de filosofia positiva. São Paulo: Abril Cultural, 1978, p. 3-4.

${ }^{64}$ PASCAL, Blaise. Pensamentos. São Paulo: Abril Cultural, 1973, p. 49-81.
} 
tudo passa). Os pitagóricos indicaram o número como arché. Já o sofista Górgias, descrente no alcance de uma "verdade" absoluta (aletheia) elegeu a "opinião" (doxa). Daí resumiu tudo à sua retórica, que seria a pura arte de persuadir. Sócrates se concentrou no homem e afirmou que sua essência é a psyché (consciência, intelecto). De Platão se diz ser o descobridor da metafísica, do ser da realidade ao mundo das ideias. Ele marca em graus o conhecimento: doxa (opinião) e epistéme (ciência). A primeira dividida em eikasía (imaginação) e pistis (crença). A segunda em: diánoia (conhecimento mediato, intermediário) e noesis (intelecção pura). Aristóteles, por sua vez, divide a ciência em três grandes ramos: ciências teoréticas (saber em si mesmo) e ciências práticas (saber para alcançar a perfeição moral) e ciência poiética ou produtiva. Deste breve resumo dos filósofos gregos já se percebe a diversidade quando se fala em conhecimento. Quanto mais quando se quer conceituar e definir ciência. Com Platão e Aristóteles estão postas todas as querelas a respeito de conhecimento e ciência: real/ideal; sujeito/objeto; ser/não ser; uno/múltiplo; qualidade/quantidade; concreto/abstrato; lugar; tempo; relação; ato/potência; ser/dever ser; fato/direito; poder/dever; finito/infinito; ciência/ não-ciência; ética; política; prática/ teoria; lógica e bom senso. Toda a filosofia e a ciência giram em torno de questões já levantadas por estes, o que muda é a resposta. Como exemplo de respostas podemos citar as descobertas da revolução científica. Francis Bacon e a teoria dos ídolos. Descartes e as regras do seu método analítico. A metafísica imanentista de Spinoza e o pluralismo monodológico de Leibniz. O empirismo de Thomas Hobbes e John Locke. Blaise Pascal e a condição humana. Os iluministas e a deusa razão. Kant e sua "crítica". Hegel e a absolutização do idealismo. O marxismo e materialismo histórico e dialético. O positivismo de Augusto Comte e a lei dos três estágios. As descobertas científicas do século XIX: geometria não-euclidiana; teoria da evolução biológica; crítica à física mecânica de Newton; a linguística; a sociologia científica; e a psicologia. $\mathrm{O}$ historicismo alemão de Dilthey e Simmel. A metodologia das ciências 
histórico-sociais de Max Weber. O pragmatismo de Peirce. A fenomologia de Husserl. O existencialismo de Jasper e Sartre. Gadamer e sua teoria do círculo hermenêutico. A filosofia da linguagem de Russell e Wittgenstein. Os filósofos analíticos de Cambridge e Oxford. Freud e a psicanálise. O desenvolvimento da ciência do século XX: lógica e as antinomias das classes; matemática e os teoremas de Gödel; a semântica de Tarski e o intuicionismo de Brouwer; as teorias da relatividade de Einstein; a teoria dos "quanta"; Mendel e a genética. O neopositivismo vienense de Kreis, Schlick e Carnap. Por fim, a filosofia da ciência com o racionalismo crítico de Popper e a epistemologia de Thomas Kuhn.

Por tudo, se ver ser a própria definição de ciência uma escolha filosófica, quiçá ideológica. Ficamos com uma postura crítica na esteira de Popper $^{65}$ e Kunh ${ }^{66}$, mas não negamos a ciência, apenas ressaltamos os limites. Limites estes próprios da condição humana tão bem ressaltadas por Pascal, que via o homem como ser capaz de grandezas e misérias. ${ }^{67}$ Esta condição humana tem consequências para a ciência. Aqui se busca afastar o perigo do cientismo (ou cientificismo, como se costuma dizer sem distinguir os termos) e dos reducionismos: sociologismo, psicologismo, politização, logicismo, racionalismo, irracionalismo, historicismo e outros. De modo especial, nossa preocupação se concentra nas ditas ciências humanas, pois já o Filósofo advertia na sua metafísica ${ }^{68}$ que as ciências da vida são avessas à ideia de verdade absoluta. E mais ainda, a ideia de verdade absoluta é uma contradição perante a concepção original de ciência, dado que esta é avessa a dogmas, mas se alicerça no progresso, na busca e descoberta incessantes. Seria sustentar uma proposição que se autoanula, a velha conhecida peritrope dos gregos.

\footnotetext{
${ }^{65}$ POPPER, Karl R.. Lógica da investigação científica. São Paulo: Abril Cultural, 1975, p. 264384.

${ }^{66} \mathrm{KUHN}$, Thomas S.. Structure of scientific revolutions. $2^{\mathrm{a}}$ ed.. Chicago: University of Chicago Press, 1970.

${ }^{67}$ Nesse sentido PASCAL, Blaise. Pensamentos. São Paulo: Abril Cultural, 1973, p. 49-81.

${ }^{68}$ ARISTÓTELES; REALI, Giovanni. Metafísica. $2^{\text {a }}$ ed.. São Paulo: Loyola, 2005. V. 1, 2 e 3.
} 
Neste diapasão é que vemos a ciência jurídica como ciência social. Não é matemática euclidiana de produto determinado e acabado. É ciência do possível, da busca incessante, do argumento e não da demonstração, do per facere (por fazer; daqui vem a correta ideia de perfeição, algo a ser feito). E não um idealismo cego e puritano, mas um realismo inquieto, comprometido com a busca, mudança, numa palavra, esperançoso. De outra forma seria ideologia anestésica das consciências e instrumento de dominação sem peias. Portanto, o direito está mais para a política e necessita da ética e da ideia de justiça.

\section{2 - Ética}

Importa fazer, resumidamente, mas não de pouca valia, algumas considerações a respeito da ética. ${ }^{69}$

A ética assumiu posição da maior relevância no cenário científico na contemporaneidade. Diante das incríveis conquistas das pesquisas científicas e de suas consequências para a humanidade e para o planeta surgiu a indagação a respeito da ética na ciência. Deve-se perceber que a questão não decorreu de início unicamente da opinião pública, mas do próprio seio da comunidade dos pesquisadores. Como exemplo de descobertas tecnológicas as quais levaram a debates sobre a ética na contemporaneidade podemos citar: na física, a energia atômica e a bomba atômica; na biologia, a genética e o projeto genoma; na química, os sintetizados (fármacos e agrotóxicos); na informática, internet e controle etc. Sendo certo que se faz mais sentir nas ciências da vida a problemática, não se pode negar o debate no âmbito da ciência em geral e, mais ainda, na própria condição humana.

\footnotetext{
${ }^{69}$ Ressaltamos de antemão que a ideia do que seja ética já apresenta diversas correntes de pensamentos e muitos são as teorias e sistemas que almejam explicá-la.
} 
No início das reflexões sobre a ética na idade contemporânea, estabeleceu-se a pergunta filosófica a respeito da origem, natureza e possibilidade da mesma.

Quanto à origem da palavra, atribuiu-se o vocábulo aos gregos. Seria a ética provinda da palavra "ethos", que para a maioria dos versados na língua grega quer dizer "morada". ${ }^{70}$ Imputando-se aos latinos a tradução da mesma por "mores", que os latinistas traduzem por "costume" e que deu origem ao termo moral. Da distinção entre "ethos" e "mores", construiu-se a distinção ética e moral. Tudo em vista de afastar a ideia negativa que há na cultura hodierna a respeito da moral, já que tal termo está associado ao ideário e sentimento moralista romano e católico medieval.

Quanto à natureza tentou-se explicá-la a partir, a nosso sentir, de uma nova ideologia, que hodiernamente acabou se tornando um "topos" no meio acadêmico. Moral seria o conjunto de normas de controle do comportamento humano inspirado em ideias e valores do cristianismo católico. Ética seria o que advém da consciência livre e refletida do homem. Esta concepção tem por base os ideais do existencialismo, humanismo laico, racionalidade, linguagem, diálogo e livre escolha. Suas naturezas estão intimamente ligadas ao fim. A moral controlaria os comportamentos por crenças e valores pré-determinados. A ética não pré-determina comportamentos, mas teria as funções de gestão do debate, informação e controle. $^{71}$

No que toca às possibilidades, cabe destacar o efeito positivo do debate, gerador de pressão dos diversos grupos sociais em torno de posturas e comportamentos de pesquisadores, empresas, Estados, governos e

\footnotetext{
${ }^{70}$ Para nós, no ocidente, a aparição pela primeira vez de tal palavra deve-se a Heráclito de Éfeso, que bradou num dos seus célebres aforismos: "Ethos antropo daimon". Nossa tradução: o demônio (deus, brilho, luz) mora no homem.

${ }^{71}$ A nosso ver, a moral estaria camuflada dentro da própria ideia de ética. Sendo certa e valiosa a reflexão trazida pela nova concepção de ética, tais como: humanismo, crítica racional, linguagem e diálogo, livre escolha e laicismo. Também é certo que a ética tem função de controle e pode conter elementos, ou seja, crenças e valores pré-concebidos que, por sua vez, estariam consciente ou inconscientemente escondidos, bem como seria um poder nas mãos dos mestres da ética.
} 
gestores. Os limites estão na própria condição humana, já que uma pessoa que se porte com rigor ético em inúmeras questões pode em algum caso resvalar. Além de que o diálogo pressupõe interlocutores de alguma forma esclarecidos e com senso crítico, o que de fato exclui muitas pessoas devido à ausência de educação escolar, bem como a forte propaganda midiática. Esta última forma a opinião não só das classes menos privilegiadas econômica e financeira, mas também dos abastados.

Fica a esperança no homem que tem a ética em si ou a faz. ${ }^{72}$

\section{3 - Questões e desafios do constitucionalismo contemporâneo}

Postas estas basilares considerações, devemos seguir rumo na reflexão adentrando na seara do fenômeno do constitucionalismo contemporâneo. Trataremos especificamente do controle da constitucionalidade e das questões políticas, da hermenêutica e interpretação constitucional, já que estes são por nós considerados os pressupostos para a ulterior avaliação da aplicação que o STF faz do devido processo legal substancial. Ainda ressaltamos que a breve exposição destes pontos far-se-á à luz da doutrina do mestre cearense Bonavides. ${ }^{73}$

A distinção entre poder constituinte e poderes constituídos juntamente com a concepção de Constituição rígida dá ensejo à necessidade do controle da constitucionalidade. Isso se explica dado que o poder constituinte é o poder soberano e originário criador da Constituição. Enquanto os poderes constituídos são inferiores e têm suas competências limitadas pela própria Constituição. Daí qualquer ato do poder constituído deve respeitar a superioridade das leis constitucionais pela simples hierarquia do ordenamento jurídico. Portanto, necessário um órgão para

\footnotetext{
${ }^{72}$ A ideia de ética depende das várias correntes e sistemas. Daí se falar em ter em si ou fazer a ética.

${ }^{73}$ BONAVIDES, Paulo. Curso de Direito Constitucional, $20^{\mathrm{a}}$ ed.. São Paulo: Malheiros, 2007.
} 
controlar os atos que porventura não sejam conforme a Constituição. O problema é estabelecer que órgão exercerá tal controle.

Duas são as categorias de controle. Primeiro, o controle formal de índole estritamente jurídica. Este busca examinar se o órgão elaborador do ato obedeceu às formalidades estabelecidas pela própria Constituição. O outro é o controle material. Caracteriza-se pelo exame do conteúdo (matéria) do ato (norma). "Busca acomodá-la aos cânones da constituição, ao seu espírito, à sua filosofia, aos seus princípios políticos fundamentais". ${ }^{74}$ Assim sendo, tal controle apresenta nítida feição política, o que oferece motivo a crítica dado seu indubitável caráter criativo posto nas mãos do órgão incumbido do controle.

Estas duas categorias deram ensejo a duas técnicas de controle. Uma por órgão político e outra por órgão jurisdicional. A criação de órgão político de controle intenta "assegurar a repartição constitucional das competências" ${ }^{75} \mathrm{O}$ controle político comporta duas categorias: "o controle prévio, que antecede a votação da lei, e o controle a posteriori, feito após a votação da lei" ${ }^{76}$ Já o controle por órgão jurisdicional contém um inegável problema, o perigo do juiz ou tribunal tomar posição política, já que não perfilhamos a tese (mito) da neutralidade do julgador. ${ }^{77}$

O controle jurisdicional se divide em duas formas: o controle por via de exceção, também chamado controle concreto e o controle por via de ação ou controle abstrato. O controle concreto se dá quando durante o procedimento jurisdicional, uma das partes pede a declaração da inconstitucionalidade da lei que se pretende aplicar ao caso. Trata-se de controle pela via incidental. Frise-se que a sentença prolatada não tem o condão de retirar a lei do ordenamento, mas apenas afasta a sua aplicação ao caso julgado, sendo, portanto, seus efeitos inter partes. Tal forma de

\footnotetext{
${ }^{74}$ Ibid., p. 299.

${ }^{75}$ Ibid., p. 300.

${ }^{76}$ Ibid., p. 301.

${ }^{77}$ Nesse sentido BONAVIDES, Paulo. Curso de Direito Constitucional, $20^{\mathrm{a}}$ ed.. São Paulo: Malheiros, 2007, p. 301.
} 
controle sofre o inconveniente de gerar insegurança jurídica pelo fato que julgadores distintos podem chegar a decisões díspares. O controle por via de ação decorre da permissiva constitucional legitimadora de alguns agentes que poderão ingressar com ação pedindo a declaração de inconstitucionalidade de uma norma. Caso a decisão acate o pedido de inconstitucionalidade a norma será banida do ordenamento, bem como terá efeito erga omnes. Esta forma de controle também apresenta problemas, quais sejam: tem natureza mais essencialmente política e pouco jurídica; baixo teor democrático, dado que nem todos os cidadãos são legitimados para propor a ação; na grande maioria das vezes as ações versam sobre conflitos entre os poderes públicos. ${ }^{78}$

Importa asseverar que o controle pela via de exceção é criação do gênio norte-americano, consagrada e conhecida no mundo jurídico por expressão em língua inglesa, qual seja: Judicial Review.

Do poder de tomar decisões ao julgar qualquer caso e, mais ainda, ao exercer o controle de constitucionalidade, o Poder Judiciário deve se sujeitar a perguntas sobre sua competência e atuação. Há atuação jurídica? Há decisões políticas? O que são as ditas questões políticas?

A maioria da doutrina constitucional pátria, baseada no pensamento do baiano Rui Barbosa, afirma "que a via de ação é política ao passo que a via de exceção é judicial" ${ }^{79}$ Contudo, Bonavides adverte a fragilidade desta distinção, já que o órgão judicial ao exercer o controle na via de exceção apenas no aspecto formal atua no âmbito do jurídico. Pois, no aspecto material (conteúdo; substância) dificilmente se pode delimitar o que seja ou não político. Todavia, o mestre cearense segue Rui Barbosa que criou um critério para delimitar o judicial e o político. Seria, então, matéria política “as faculdades ou competências atribuídas pela Constituição no seu texto

\footnotetext{
${ }^{78}$ Nesse sentido BONAVIDES, Paulo. Curso de Direito Constitucional, 20ª ed.. São Paulo: Malheiros, 2007, p. 308.

${ }^{79}$ BONAVIDES, Paulo. Curso de Direito Constitucional, $20^{\mathrm{a}}$ ed.. São Paulo: Malheiros, 2007, p. 317.
} 
aos diferentes ramos de soberania - o Executivo, o Legislativo e o Judiciário" 80 . Já a matéria jurídica seria "os direitos do indivíduo com as suas garantias expressas em disposição taxativas". ${ }^{81}$ Bonavides ainda lembra que tal critério de distinção foi criado numa concepção de Estado liberal, mas sustenta poderem permanecer na atual concepção de Estado social, desde que se amplie as garantias de individuais a todas as garantias asseguradas às pessoas humanas.

A nosso ver, com a devida vênia aos queridos conterrâneos, tal distinção não pode ser sustentada. Pois, afirmar uma matéria estritamente jurídica seria amesquinhar o conceito de político. A ideia de que político se restringe a relação entre as faculdades e competências entre Executivo, Legislativo e Judiciário é sectária de uma filosofia política liberal conservadora. Até mesmo sustentar a distinção pura entre político e jurídico não pode prosperar numa filosofia política e social atual comprometida com a democracia verdadeiramente aberta e participativa de todos os cidadãos sem nenhuma forma de distinção. O que no máximo poder-se-ia propor seria uma escala para o teor das decisões, onde sempre conteria o político e o jurídico, variando ambas livremente ao sabor do caso concreto. E mesmo assim, tal medida seria um mero juízo de probabilidade. No mais, estaríamos construindo um mito por conveniência pragmática. Como exemplo argumentativo de suporte à posição por nós defendida basta perceber que da própria ideia de separação de poderes, ou melhor, das funções de poder, encontramos o político em sua concepção lata no Judiciário. Pois a função de poder é dada ao Judiciário. E poder não pode ser entendido como mero poder jurídico. Não há como repartir o fenômeno “poder” em jurídico e político. Poder sempre terá conteúdo político. Poder pressupõe relação. E relação sempre envolve poder. Poder e relação geram política lato senso. Logo, seria por demais artificioso se falar em jurídico

\footnotetext{
${ }^{80}$ Ibid., p. 318.

${ }^{81}$ Rui Barbosa, trabalhos jurídicos, XI, Obras seletas de Rui Barbosa, p. 98 apud BONAVIDES, Paulo. Curso de Direito Constitucional, 20ª ed.. São Paulo: Malheiros, 2007, p. 318.
} 
antagonicamente a político. Preferimos perfilhar o realismo sem deixar de se comprometer com a autocrítica incessante.

Enfim, chegamos ao último pressuposto que nos propusemos abordar antes de avaliar os julgados do STF, a hermenêutica e seus métodos de interpretação. $\mathrm{O}$ que se pretende é simplesmente expor o tema resumidamente, já que não temos a pretensão de oferecer uma resposta, um método supostamente acabado. ${ }^{82}$ Para tanto, confessadamente nos balizaremos no pensamento de Bonavides. ${ }^{83}$

A interpretação das normas jurídicas no sentido clássico consolidado por Savigny seria "a reconstrução do conteúdo da lei". ${ }^{84}$ Sendo uma operação de caráter lógico-formal e, portanto, técnica, visando obter o sentido objetivo da norma.

A doutrina costuma didaticamente classificar a interpretação distinguindo-a quanto às fontes, aos meios e aos resultados. Quanto às fontes o critério se baseia na qualidade do sujeito ou agente intérprete. Emanando do legislador se diz autêntica, do juiz, judiciária, do jurista, doutrinária. Autêntica será quando o legislativo mesmo elabora outra norma no intuito de estabelecer o significado e alcance da norma antecedente. Judiciária, por sua vez, será a interpretação emanada das decisões dos juízes e tribunais quando da aplicação da norma. Doutrinária, enfim, a interpretação saída da pena dos mestres e doutores, cultores, do direito. Esta se alicerça na ideia de autoridade, reputação intelectual de quem sustenta.

Quanto aos meios o critério vem a ser o método técnico empregado, podendo ser o gramatical, o lógico e o analógico. O método gramatical também chamado filológico, literal ou léxico, se prende à análise do texto

\footnotetext{
${ }^{82}$ Vale ressaltar que o estudo da hermenêutica jurídica é tema dos mais complexos, não comportando esgotamento nem mesmo numa magistral tese. A nosso entender seria o âmago do Direito.

${ }^{83}$ BONAVIDES, Paulo. Curso de Direito Constitucional, 20 a ed.. São Paulo: Malheiros, 2007, p. 437-524.

${ }^{84}$ Savigny, Juristische Methodenlehre, pp. 18/20 apud BONAVIDES, Paulo. Curso de Direito Constitucional, 20a ed.. São Paulo: Malheiros, 2007, p.438.
} 
da norma, ao significado da palavra, da expressão, da frase por técnicas gramaticais e etimológicas. A interpretação lógica busca o sentido da norma do cotejo com as demais normas, ainda mediante os fundamentos da norma na sua origem e elaboração (occasio legis), bem como o motivo, os fins. Deve levar em conta a ratio ou mens. ${ }^{85}$ Já a dita interpretação analógica se baseia na ideia de unidade e completude do sistema, pois no caso de não haver uma norma, ou seja, na ocorrência de uma lacuna, se deve integrar o sistema por direito já existente implicitamente. Portanto, na verdade, como adverte Bonavides ${ }^{86}$, não se trata de interpretação, mas de "um processo de integração por analogia". Contudo, indubitavelmente se firmou nos estudos jurídicos a ideia de interpretação secundum legem, praeter legem e contra legem. ${ }^{87}$ Ainda, se distingue a analogia em analogia legis e analogia juris, dependendo do grau de generalização feito. A primeira, numa generalização estreita, toma uma lei ou complexo de lei para obter uma norma para o caso. A segunda, por sua vez, numa generalização larga, extrai dos princípios gerais de direito uma norma.

No tocante à interpretação quanto aos resultados, dado se referir ao produto alcançado e obtido, se fala em declarativa, extensiva e restritiva. A primeira, segundo Bonavides ${ }^{88}$, se dá

"quando na reconstrução do pensamento pelo intérprete coincide a interpretação gramatical com a interpretação lógica, isto é, a letra da lei corresponde ao sentido que lhe é atribuido pela razão ("cum in verbis nulla ambiguitas est, non debet admitti voluntatis quaestio").

Na segunda, a lei exprime menos do que queria (lex minus scripsit quam voluit). Daí a possibilidade do intérprete dizer mais, criar. A terceira e derradeira, a lei exprime mais do que queria (lex plus scripsit quam voluit). Aqui interpretação dirá menos.

\footnotetext{
${ }^{85}$ A depender da escola jurídica pode se falar em mens legis (mente da lei; objetivistas em geral) ou mens legislatori (mente do legislador; subjetivistas em geral).

${ }^{86}$ BONAVIDES, Paulo. Curso de Direito Constitucional, $20^{\mathrm{a}}$ ed.. São Paulo: Malheiros, 2007, p. 442.

${ }^{87}$ BOBBIO, Norberto. O positivismo Jurídico: Lições de filosofia do direito. São Paulo: Ícone, 2006, p. 170.

${ }^{88}$ BONAVIDES, Paulo. Curso de Direito Constitucional, 20ª ed.. São Paulo: Malheiros, 2007, p. 444.
} 
Destes métodos clássicos alguns juristas remodelaram a interpretação passando a falar em outros métodos: lógico-sistemático, históricoteleológico e voluntarista. Segundo Bonavides ${ }^{89}$, volvidos todos primeiro para o "espírito" do que para a "letra" das leis. No método lógicosistemático se diz lógico por utilizar elementos da lógica formal, os argumentos lógico (e.g., a fortiori, a posteriori, a contrario sensu, sedes materiae e absurdo) e sistêmico por enfeixar a ideia de um todo ou unidade ordenada, onde as normas convivem em harmonia.

O método histórico-teleológico se caracteriza no seu elemento histórico pela busca dos fatores políticos, econômicos e sociais à época da elaboração da norma (occasio legis) e no seu elemento teleológico que pretende obter o fim (télos) da norma, ou seja, o resultado. ${ }^{90}$ Há que se ressaltar que este método com a escola do direito livre também é chamado de interpretação evolutiva ou progressiva, já que o intérprete, com fito de adaptar a norma à realidade do caso, poderá valendo da sua própria vontade criar a norma.

O método voluntarista se consagra com a Teoria Pura do Direito de Hans Kelsen. De forma lapidar Bonavides ${ }^{91}$ expõe a tese de Kelsen,

a interpretação é em essência um ato de decisão (um ato volitivo, um "Sinngebung"), e não um ato de cognição (um ato intelectivo, um "Sinnverständnis"), de sorte que na hermenêutica jurídica, quando se interpreta uma norma, o intérprete, ao eleger um de seus possíveis significados, guia-se mais pela vontade do que pela inteligência, ou seja, pesa mais sobre a escolha a primeira do que a segunda.

\footnotetext{
${ }^{89}$ Ibid., 445.

${ }^{90}$ Saber se o fim almejado será a mens legis ou mens legislatoris dependerá do intérprete escolher se filiar a corrente objetivista ou subjetivista. Vale aqui esclarecer a confusão que se faz ao traduzir mens legis por vontade da lei e mens legislatoris por vontade do legislador. Não se trata de "vontade", mas de mente, alma. Vontade seria voluntas, voluntatis. Se o que se pretende dizer é o querer, vontade, desejo, fim, se deve utilizar o vocábulo voluntas. De outro lado, se a pretensão é falar da razão, cognição, motivo, melhor seria se usar o termo intellegentia. Dado que é sabido que os gregos de forma geral compreendiam o homem como psyché e soma. Sendo a psyché formada por três faculdade: memória, inteligência e vontade. Os latinos, no geral, conservaram a tradição grega, e traduziram psyché por mens (mente, alma) e soma por corpus (corpo). A mens compreenderia as três faculdades, que em latim seria: memoria, ae; intelligentia, ae; voluntas, atis. ${ }^{91}$ HANS, Kelsen, Reine Rechtslehre, 1934, p. 90 apud BONAVIDES, Paulo. Curso de Direito Constitucional, 20ª ed.. São Paulo: Malheiros, 2007, p. 448.
} 
Diante das várias escolas de interpretação do direito criou-se a distinção entre objetivistas e subjetivistas. Em suma, afirma-se que a corrente objetivista propugna a tese que o intérprete deve se cingir ao exame do texto da lei. Ao passo que a corrente subjetivista defende a inquirição da "vontade" do legislador.

Importa lembrar que os métodos, até aqui apresentados, estão ligados, na sua maioria, ao pensamento positivista-formal da época do Estado liberal. Dada às transformações sociais, políticas e econômicas ocorridas na Europa no decurso do século XVIII e XIX, o modelo liberal de Estado, de Direito, de Sociedade entraram em crise. O século XX foi palco do desenvolvimento de nova trama, ou seja, a nova realidade social exigente de um novo modelo, consentâneo com os valores então vigentes, de modo eminente a justiça. Se o modelo liberal pregava um Estado distante do social, não interventor, um Direito abstrato e de segurança jurídica e um ideário de Sociedade conservadora, o novo modelo busca e preza pela prevalência da estatização ou politização, pelo concretismo e justiça e pelo ideário de dinâmica e justiça social. Diante dos novos fatos e da crise surge uma nova hermenêutica constitucional e, mais ainda, já no alvorecer do século XX aparecem as Constituições sociais (e.g., mexicana de 1917 e Weimar de 1919).

No âmbito da Hermenêutica, juristas alemães, capitaneado por Rudolf Smend, criaram um novo método interpretativo constitucional, o integrativo ou científico-espiritual. Smend parte da concepção de que a Constituição é um ordenamento em cujo seio transcorre a realidade vivencial do Estado, o seu processo de integração. ${ }^{92}$ Ele entendia que a Constituição seria formada por um conjunto de fatores distintos integrados e possuidores de diversos graus de legitimidade, daí ser necessário tomá-la sempre como um todo ao interpretá-la. ${ }^{33}$ Critica os formalistas que apesar

\footnotetext{
${ }^{92}$ Ibid., p. 477.

${ }^{93}$ Nesse sentido BONAVIDES, Paulo. Curso de Direito Constitucional, $20^{a}$ ed.. São Paulo: Malheiros, 2007, p. 478.
} 
de sua indiferença com a realidade da vida, a concretude da existência, ainda violenta a norma jurídica, quando ao aplicá-la o faz fora do conjunto, do todo Constitucional.

Em 1953, Theodor Viehweg publica sua obra Tópica e Jurisprudência, onde defende que o pensamento jurídico seria tópico. Viehweg trouxe à baila para o Direito o velho pensamento dos topoi por Aristóteles escrito na sua obra Organum, mais especificamente no capítulo (ou livro, como chamavam os antigos) Topoi. O pensamento tópico é a técnica de pensar o problema. ${ }^{94}$ Uma teoria de argumentação jurídica, preocupada com o caso concreto, mergulhada na práxis, para obtenção de resultado materialmente "justo".

A recepção da obra de Viehweg entre os juristas fez eclodir inúmeras posições a respeito do pensamento tópico e sua aplicação. Juntamente com a corrente científica-espiritual de Smend, a tópica foi inspiração para um novo método de interpretação da hermenêutica, o chamado método concretista. Vários juristas de renomada desenvolveram seus pensamentos no intuito de consolidar o método concretista, bastando citar os notáveis Konrad Hesse $^{95}$, Friedrich Müller ${ }^{96}$, Peter Häberle ${ }^{97}$.

O método concretista de interpretação gravita ao redor de três elementos básicos: a "norma" que se vai concretizar, a "compreensão prévia" do intérprete e o "problema concreto a resolver". 98

Hesse afirma que o teor da norma só se completa no ato interpretativo. A “concretização” e a “compreensão” só são possíveis em

\footnotetext{
${ }^{94}$ Viehweg, Topik und Jurisprudenz, p.167 apud BONAVIDES, Paulo. Curso de Direito Constitucional, 20ª ed.. São Paulo: Malheiros, 2007, p. 491.

${ }^{95}$ HESSE, Konrad. A força normativa da Constituição. Porto Alegre: Sergio Antonio Fabris Editor, 1991.

${ }^{96}$ MÜLLER, Friedrich. Teoria estruturante do Direito I. $2^{\mathrm{a}}$ ed. São Paulo: Revista dos Tribunais, 2009.

${ }^{97}$ HÄBERLE, Peter. Hermenêutica Constitucional. Porto Alegre: Sergio Antonio Fabris Editor, 1997.

${ }^{98}$ BONAVIDES, Paulo. Curso de Direito Constitucional, $20^{\mathrm{a}}$ ed.. São Paulo: Malheiros, 2007, p. 482.
} 
face de um problema concreto. E ainda que a “compreensão prévia” deve ser fundamentada e conscientizada..$^{99}$

Müller desenvolveu um método de concretização baseado na ideia de estrutura da normatividade. Ou seja, a norma só pode ser compreendida ao se levar em conta a estrutura da mesma. A norma não está apenas no texto, sendo, portanto, dogmatismo preconceituoso cingir-se no buscar a mens legis ou a mens legislatoris. Na verdade, o conteúdo encontra-se no âmbito da norma. O âmbito engloba o texto, como diretiva e limite da concretização, estrutura formal, e o conteúdo, estrutura material concreta, a realidade.

O método proposto por Müller contém os seguintes elementos de concretização da norma: elementos metodológicos; elementos do âmbito da norma; elementos dogmáticos; elementos teóricos; elementos técnicos de solução; e elementos político-jurídicos. Müller ainda estabeleceu uma hierarquia entre os elementos. Na ótica de Bonavides aqui reside o ponto fraco da metodologia. Nas palavras do mestre cearense:

"Depois de abrir-se amplamente para a realidade, o concretismo de Müller tem sua última postulação assentada numa estrutura jurídica limitativa, decorrente da hierarquia dos elementos hermenêuticos empregados para definir a normatividade e que se discriminam, na sua prevalência, de modo estimativo, mais técnico do que axiológico ou ideológico". ${ }^{100}$

Häberle preconiza um método de concretização constitucional aberto. Seu fundamento encontra-se na ideia de democratização do processo interpretativo. Ou seja, a interpretação deve ser feita levando em conta a participação efetiva de todos os cidadãos, num verdadeiro pluralismo democrático de uma sociedade aberta. Esta teoria pressupõe:

o alargamento do círculo de intérpretes da Constituição; o conceito de interpretação como um processo aberto e público; e a referência desse conceito à Constituição mesma, como realidade constituída e "publicização". ${ }^{101}$

\footnotetext{
${ }^{99}$ Ibid., p. 481.

100 Ibid., p. 509.

101 Ibid., p. 509.
} 
Não se pode deixar de falar da obra de Niklas Luhmann que defende, na sua obra Sociologia do Direito, ser o Direito um sistema autopoiético. ${ }^{102} \mathrm{E}$ na doutrina pátria se destaca o jusfilósofo pernambucano Marcelo Neves ${ }^{103}$, ao sustentar, na esteira de Luhmann, a ideia de constitucionalização simbólica.

Por fim, consideramos ser o problema hermenêutico uma verdadeira aporia. Basta ver que no ocidente desde os gregos se peleja em torno da hermenêutica. ${ }^{104}$ Chegam estes a atribuir ao deus Hermes a tarefa de intérprete. Daí o termo Hermenêutica. Também não concordamos com aqueles que afirmam ser possível o intérprete ficar apenas nos limites supostamente técnicos e ser despudorado cinismo ou ceticismo angustiante pensar diferente. ${ }^{105}$ Negar os limites de qualquer método de interpretação soa a idealismo extremo. Afirmar que a interpretação se mantém nos trilhos da lógica seria positivismo-formalista agudo, caindo-se na crítica já feita por Smend de violência à norma, apesar de se tentar negar tal ato.

\section{4 - O devido processo legal substancial e sua aplicação pelo STF}

Enfim, chegado é o momento de debruçarmo-nos sobre os julgados do STF. Tendo em vista que o faremos a partir de todas as considerações e preliminares até então apresentadas.

Para tanto nos valemos do item pesquisa de jurisprudência do site do STF. A busca foi feita pelos termos: devido processo legal ou princípio da razoabilidade ou princípio da proporcionalidade. Em seguida escolhemos

\footnotetext{
${ }^{102}$ LUHMANN, Niklas. Sociologia do direito I e II. Rio de Janeiro: Tempo Brasileiro, 1983. ${ }^{103}$ NEVES, Marcelo. A constitucionalização simbólica. São Paulo: Editora Acadêmica, 1994. ${ }^{104}$ Nesse sentido REBOUL, Olivier. Introdução à retórica. São Paulo: Martins Fontes, 1998, p. 01-90.

${ }^{105}$ Nesse sentido FERRAZ JUNIOR, Tércio Sampaio. Introdução ao Estudo do Direito: técnica, decisão, dominação. $4^{\mathrm{a}}$ ed.. São Paulo: 2003, p.359. Vale lembrar que Aristóteles, na Metafísica, não afirma que a techné possa ser aplicada infalivelmente na obtenção do conhecimento no domínio das chamadas ciências humanas. Estas têm por objeto o homem, ser de vontade e paixões, sendo obra impossível saber plenamente o que as determina. Techné está para as ciências naturais. Ciências humanas estão no reino do possível e do provável.
} 
aleatoriamente 15 decisões. O resultado foi desalentador, dado que todas apresentavam os termos apenas na condição de mero "topos". Ou seja, a decisão simplesmente fazia referência ao instituto sem avaliar como incide no caso concreto julgado.

Por fim, diante dos supracitados resultados decidimos escolher por ministro. Escolhemos casos julgados em que prevaleceram os votos dos exministros Moreira Alves e Sydney Sanches, bem como dos atuais ministros Gilmar Mendes e Joaquim Barbosa, já que assim podem ser percebidas as mudanças no decorrer dos anos, dado à alteração da composição dos membros do STF. Foram escolhidas como modelo as: ADI 1479 MC, Rel. Ministro Moreira Alves; ADI 1992, Rel. Ministro Sydney Sanches; ADI 1976, Rel. Ministro Joaquim Barbosa; e RE 511.961, Rel. Ministro Gilmar Mendes.

No intuito de facilitar a avaliação transcrevemos os trechos de cada decisão no ponto em que importa para o tema a que nos propusemos pesquisar, ou seja, o devido processo legal substancial. Como método didático faremos os comentários pertinentes após cada trecho selecionado das decisões.

Iniciemos com a ADI 1479-0 $0^{106}$, relatada pelo ex-ministro Moreira Alves:

(...) “A Lei n. 10.778, de 07/05/96, objeto de impugnação na presente sede de controle concentrado de constitucionalidade, tem o seguinte conteúdo normativo (fls. 52):

"Art. $1^{\circ}$ - É obrigatório, para os veículos automotores de qualquer categoria, nas rodovias estaduais do Rio Grande do Sul, o uso de faróis baixos ligados durante as vinte e quatro horas do dia.

multa.” (...)

Art. $2^{\circ}$ - O descumprimento desta Lei importará em pena de

(...) Sustenta-se que a Lei estadual n. 10.778/96 veicularia conteúdo normativo impregnado do vício da irrazoabilidade, eis a exigência dela constante - sequer precedida de "maiores reflexões técnicas" (fls. 10) - teria resultado do capricho meramente arbitrário do legislador local.

${ }^{106}$ ADI 1479 MC, Rel. Ministro Moreira Alves, Brasília, 07 de novembro de 1996. 
Coloca-se em evidência, neste ponto, em função das alegações deduzidas pela autora, o tema concernente ao princípio da proporcionalidade, que se qualifica - enquanto coeficiente de aferição da razoabilidade dos atos estatais (CELSO ANTÔNIO BANDEIRA DE MELLO, "Curso de Direito Administrativo", p. 56/57, itens $n^{\circ}$ s. 18/19, $4^{\text {a }}$ ed., 1993, Malheiros; LÚCIA VALLE FIGUEIREDO, "Curso de Direito Administrativo", p. 46, item n ${ }^{\circ} .3 .3,2^{\text {a }}$ ed., 1995, Malheiros) - como postulado básico de contenção dos excessos do Poder Público.

Essa é a razão pela qual a doutrina, após destacar a ampla incidência desse postulado sobre os múltiplos aspectos em que se desenvolve a atuação do Estado - inclusive sobre a atividade estatal de produção normativa - adverte que o princípio da proporcionalidade, essencial à racionalidade do Estado Democrático de Direito e imprescindível à tutela mesma das liberdades fundamentais, proíbe o excesso e veda o arbítrio do Poder, extraindo a sua justificação dogmática de diversas cláusulas constitucionais, notadamente daquela que veicula, em sua dimensão substantiva ou material, a garantia do due process of law(...)."

Da leitura da decisão percebe-se rapidamente a ausência de qualquer referência aos elementos adequação, necessidade e proporcionalidade em sentido estrito que compõem o princípio da proporcionalidade. Ainda se nota o uso do termo irrazoabilidade e princípio da proporcionalidade. $\mathrm{O}$ primeiro, segundo as palavras do relator, fora empregado nas alegações deduzidas pela autora ao atacar o conteúdo da norma que estaria impregnado do vício de irrazoabilidade. Até aqui tudo bem, já que fora o autor que usou o termo irrazoabilidade. Todavia, o relator diz que tais alegações amoldam-se ao tema do princípio da proporcionalidade e que este "se qualifica - enquanto coeficiente de aferição da razoabilidade dos atos estatais - como postulado básico de contenção dos excessos do Poder Público”. Para justificar tal assertiva cita a doutrina. Neste trecho fica claro a utilização dos termos irrazoabilidade e princípio da proporcionalidade como sinônimos.

No último parágrafo por nós aqui transcrito, o ministro ainda alegando base na doutrina afirma ser o princípio da proporcionalidade um "postulado", o que realmente é dito por Humberto Ávila ${ }^{107}$, bem como diz ser "essencial à racionalidade do Estado Democrático de Direito e imprescindível à tutela mesma das liberdades fundamentais", que é uma

\footnotetext{
${ }^{107}$ ÁVILA, Humberto. Teoria dos Princípios: da definição à aplicação dos princípios jurídicos. $10^{\mathrm{a}}$ ed. São Paulo: Malheiros, 2009, p. 136.
} 
proposição acertada. Em seguida, fala em proibição de excesso ao dizer: “proíbe o excesso e veda o arbítrio do Poder". Seria o Übermassverbot dos alemães, ou melhor, da Corte constitucional alemã. Também sustenta que o princípio seria extraído de "diversas cláusulas constitucionais", como fazem alguns doutrinadores, mas perfilha o entendimento de que se justifica "notadamente daquela que veicula, em sua dimensão substantiva ou material, a garantia do due process of law".

Por fim, vale ressaltar que do trecho citado aparece o dizer: "sequer precedida de "maiores reflexões técnicas"”, o qual o relator poderia ter despertado para a necessidade da avaliação, por excelência, dos elementos necessidade e adequação.

Agora vejamos a ADI $1992 \mathrm{MC}^{108}$, relatada pelo então Ministro Sydney Sanches:

(...) " 1 - IRRAZOABILIDADE - Até mesmo pelo princípio da irrazoabilidade, o dispositivo não merece guarida, de vez que obriga um dos contratantes (a escola) a continuar prestando serviços ao outro, que descumpre sua obrigação elementar de pagar. Choca-se contra o dispositivo no art. 1092 do Código Civil, privilegia um contratante em detrimento do outro e prejudica os alunos adimplentes e cumpridores das obrigações assumidas, pois acabam arcando com o custo-de-ensino daqueles que não pagam.

A escola particular mantém os serviços que presta e seu nível de qualidade graças ao que arrecada de seus alunos. Com a arrecadação, paga professores, empregados, serviços públicos, impostos, contribuição previdenciária e FGTS. Tem de pagá-los em dia, sob pena de altos juros, multa e correção monetária.

Não recebendo dos alunos, não tem os recursos necessários para arcar com os custos, sujeitando-se a cortes de serviços, greve de professores, despesas financeiras e queda da qualidade do que oferece. Tem que recorrer a empréstimos e encargos para suprir a deficiência de receita.

O preço da anuidade escolar é calculado pela divisão do custo total do ensino pelo número de alunos matriculados. Se alguns não pagam, este custo é dividido por um número menor de alunos, os que honram em dia seus compromissos. Assim, os bons, os que assumem e cumprem em dia suas obrigações são prejudicados, porque ficam mais onerados.

A escola é expropriada e confiscada em seu trabalho pois presta os serviços e não recebe dos inadimplentes, expropriação que tem cunho financeiro, pois se reflete em juros, multa e correção que tem de pagar ou na queda de

${ }^{108}$ ADI 1992 MC, Rel. Ministro Sydney Sanches, Brasília, 18 de agosto de 1999. 
qualidade dos serviços oferecidos ou em prejuízo mesmo. Trabalha de graça para eles.

A Medida Provisória, então, privilegia os piores, os inadimplentes, os caloteiros, em detrimento dos outros contratantes - a escola - e os alunos que primam por serem honestos e adimplentes."

A decisão em comento trata do pedido de declaração de inconstitucionalidade da Medida Provisória n ${ }^{\circ}$ 1.733-60 de 08 de abril de 1999 e suas reedições. No ponto em que nos interessa analisar o art. $6^{\circ}$ que

reza: "São proibidas a suspensão de provas escolares, a retenção de documentos escolares, inclusive os de transferência, ou a aplicação de quaisquer outras penalidades pedagógicas, por motivo de inadimplência.”.

A primeira constatação da avaliação do texto transcrito é a utilização do termo "princípio da irrazoabilidade". Quanto ao termo princípio da proporcionalidade, este em momento algum é citado. $\mathrm{O}$ ministro afirma a ofensa ao "princípio da irrazoabilidade", mas não se reporta aos termos adequação, necessidade e proporcionalidade em sentido estrito. Ele apenas lança uma série de argumentos. Vejamos se estes no seu conteúdo se enquadrariam em algum dos elementos do princípio da proporcionalidade.

O relator argumenta que as escolas particulares dependem do pagamento dos alunos para prestar seu serviço, sem os quais a qualidade do serviço ficaria comprometida ou teria que se recorrer a empréstimos onerosos. No primeiro caso os que pagam ficariam prejudicados, já que pagam por um serviço e acabam recebendo um serviço de pior qualidade. No segundo, a escola é que absorveria o prejuízo pelo inadimplemento e teria seus lucros diminuídos ou até mesmo fecharia o exercício financeiro com saldo devedor maior que o credor, o que poder-se-ia dar ensejo à falência. Este argumento prestar-se-ia para preencher o elemento necessidade, já que seria meio adequado, ou seja, medida apta para fomentar o resultado pretendido, qual seja, forçar o adimplemento contratual (pagamento das mensalidades). Contudo, não preenche o 
conteúdo do elemento necessidade, dado que esse pressupõe um exame comparativo, ou seja,

um ato estatal que limite um direito fundamental é somente necessário caso a realização do objetivo perseguido não possa ser promovido, com a mesma intensidade, por meio de outro ato que limite, em menor medida, o direito fundamental atingido. ${ }^{109}$

Parece-nos que a medida do art. $6^{\circ}$ seja necessária, já que não há outras medidas de mesma intensidade (e.g., temor de ter seu cadastro negativado ou cobrança por via judicial) que alcancem os objetivos pretendidos (pagamento das mensalidades). Contudo, o mesmo não se pode dizer do elemento proporcionalidade em sentido estrito, pois este

consiste em um sopesamento entre a intensidade da restrição ao direito fundamental atingido e a importância da realização do direito fundamental que com ele colide e que fundamenta a adoção da medida restritiva. ${ }^{110}$

No caso em tela, o direito à educação não pode ser menosprezado em face da realização do crédito das escolas mesmo que este seja postergado dado à inadimplência dos pais.

Quanto ao argumento de que os alunos são tratados de forma desigual, já que os adimplentes pagariam pelos inadimplentes, não poderia prosperar. Não são os alunos que pagam, mas seus pais. O que se poderia alegar seria a possibilidade de pior qualidade de ensino ou perigo de não haver vagas suficientes nas escolas particulares pelo fato de muitas falirem. Nesta hipótese sim, poder-se-ia sopesar o direito à educação de uns com os outros.

Passemos a avaliação do RE $511.961^{111}$, relatado pelo Ministro Gilmar Mendes:

(...) EMENTA: JORNALISMO. EXIGÊNCIA DE DIPLOMA DE CURSO SUPERIOR, REGISTRADO PELO MINISTÉRIO DA EDUCAÇÃO, PARA O EXERCÍCIO DA PROFISSÃO DE JORNALISTA. LIBERDADES DE PROFISSÃO, DE EXPRESSÃO E DE INFORMAÇÃO. CONSTITUIÇÃO DE 1988 (ART. $5^{\circ}$, IX E XIII, E ART. 220, CAPUT E $\S 1^{\circ}$ ). NÃO RECEPÇÃO DO ART. $4^{\circ}$, INCISO V, DO DECRETO-LEI No 972, DE 1969.(...)

\footnotetext{
${ }^{109}$ SILVA, Luís Virgílio Afonso da. "O proporcional e o razoável”. Revista dos Tribunais. V. 798, p. 23-50, abril de 2002, p. 38 .

${ }^{110}$ Ibid., p. 40.

${ }^{111}$ RE 511.961, Rel. Gilmar Mendes, Brasília, 17 de junho de 2009.
} 
(...) A doutrina constitucional mais moderna enfatiza que, em se tratando de imposição de restrições a determinados direitos, deve-se indagar não apenas sobre a admissibilidade constitucional da restrição eventualmente fixada (reserva legal), mas também sobre a compatibilidade das restrições estabelecidas com o princípio da proporcionalidade.

Essa orientação, que permitiu converter o princípio da reserva legal (Gesetzesvorbehalt) no princípio da reserva legal proporcional (Vorbehalt des verhältnismässigen Gesetzes), pressupõe não só a legitimidade dos meios utilizados e dos fins perseguidos pelo legislador, como também a adequação desses meios para consecução dos objetivos pretendidos (Geeignetheit) e a necessidade de sua utilização (Notwendigkeit oder Erforderlichkeit).

O subprincípio da adequação (Geeignetheit) exige que as medidas interventivas adotadas mostrem-se aptas a atingir os objetivos pretendidos. $\mathrm{O}$ subprincípio da necessidade (Notwendigkeit oder Erforderlichkeit) significa que nenhum meio menos gravoso para o indivíduo revelar-se-ia igualmente eficaz na consecução dos objetivos pretendidos.

Um juízo definitivo sobre a proporcionalidade da medida há também de resultar da rigorosa ponderação e do possível equilíbrio entre o significado da intervenção para o atingido e os objetivos perseguidos pelo legislador (proporcionalidade em sentido estrito).

Portanto, seguindo essa linha de raciocínio, é preciso analisar se a lei restritiva da liberdade de exercício profissional, ao definir as qualificações profissionais, tal como autorizado pelo texto constitucional, transborda os limites da proporcionalidade e atinge o próprio núcleo essencial dessa liberdade. (...)

(...) No exame da proporcionalidade, o art. $4^{\circ}$, inciso V, do Decreto-Lei $\mathrm{n}^{\circ}$ 972/1969 não passa sequer no teste da adequação (Geeignetheit).

É fácil perceber que a formação específica em curso de graduação em jornalismo não é meio idôneo para evitar eventuais riscos à coletividade ou danos efetivos a terceiros. De forma extremamente distinta de profissões como a medicina ou a engenharia, por exemplo, o jornalismo não exige técnicas específicas que só podem ser aprendidas em uma faculdade. O exercício do jornalismo por pessoa inapta para tanto não tem o condão de, invariável e incondicionalmente, causar danos ou pelo menos risco de danos a terceiros. A consequência lógica, imediata e comum do jornalismo despreparado será ausência de leitores e, dessa forma, a dificuldade de divulgação e de contratação pelos meios de comunicação, mas não o prejuízo direto a direitos, à vida, à saúde de terceiros. (...)

Eis um exemplo de julgado que além de expor sucintamente a doutrina a respeito do princípio da proporcionalidade faz a avaliação dos elementos. No caso o dispositivo nem sequer resistiu ao exame da adequação. Vale salientar ainda que o ministro utilizou o termo princípio da proporcionalidade e subprincípio. 
Por fim, debrucemo-nos sobre a ADI $1976^{112}$, relatada pelo Ministro Joaquim Barbosa:

(...) Exigir que o administrado deposite uma determinada quantia ou arrole bens como requisito ao exercício do direito de recorrer equivale, na prática, à supressão desse direito. E justamente aí se encontra a violação ao núcleo essencial do direito de recorrer administrativamente. $\mathrm{O}$ exame de proporcionalidade comprova isto.

Não se faz presente a exigência da adequação, que visa a aferir se o meio leva efetivamente à realização do fim, quando impõe o depósito prévio ou o arrolamento de bens e direitos como condição sine qua non para o manejo do recurso. Ao cobrar quantia para admitir recurso administrativo, não consegue a Administração evitar que o administrado, posteriormente, venha a impedir judicialmente os efeitos da decisão administrativa. É criado um entrave que pode não satisfazer o fim da administração em receber certa quantia.

Quanto à necessidade, ou seja, a não existência de outro meio eficaz, também não se configura no caso. O depósito prévio ou o arrolamento de bens e direitos criam um discrimen infundado em detrimento do administrado, exigindo que este deposite quantia de que muitas vezes não é possuidor ou arrole bens que fazem parte de seu patrimônio, quantia essa ou bens e direitos que ficam imobilizados enquanto o recurso é analisado. Por outro lado, é descabida qualquer tentativa de se transformar o depósito prévio em condição necessária ao atingimento do objetivo de se ter um procedimento administrativo célere.

No que tange à razoabilidade, o confronto entre o direito ao recurso administrativo e a pretensão da administração de reter quantias ou exigir o arrolamento de bens e direitos até que ela própria analise um recurso, há de resultar na preponderância do direito do cidadão a levar adiante a sua irresignação contra uma medida que considera ilegal ou injusta, inclusive por razões de ordem prática. Vale dizer a solução mais favorável ao administrativo deve prevalecer, mesmo porque a exigência do depósito prévio ou o arrolamento têm o efeito perverso de contribuir para a sobrecarga do Judiciário, já inacessível, como todos sabem, a parcelas significantes da população." (...)

O último dos julgados analisado por nós apresenta correto exame dos elementos. Percebe-se que o ministro usa o termo "exame de proporcionalidade”, o que a rigor não está errado. Contudo, escorrega ao falar em "razoabilidade", quando deveria dizer proporcionalidade em sentido estrito.

Enfim, podemos concluir que em algumas decisões a aplicação do devido processo legal substancial é realizada a contento.

\footnotetext{
${ }^{112}$ ADI 1976, Rel. Ministro Joaquim Barbosa, Brasília, 28 de março de 2007.
} 


\section{CONCLUSÃO}

Inicialmente, consideramos muito importante louvar o instituto do devido processo legal substancial. Basta considerar a sua origem e desenvolvimento para perceber a luta e o grande esforço que exigiu a sua previsão como norma e, mais ainda, a sua aplicação judicial. Contudo, não se pode negar as deficiências e as dificuldades que existem na teoria e na aplicação do instituto em tela.

No âmbito das indagações sobre ciência e lógica ficamos com os filósofos contemporâneos Popper e Kuhn, os quais tecem críticas relevantes

às mesmas. É certo que não se pode negar o valor da lógica-formal, bem como deixar de respeitar a consciência dos positivistas convictos, mas também não se deve e nem se pode escapar de dizer que há a possibilidade da tentativa ardilosa, por parte de alguns, de iludir consciências sob a falsa garantia da tecnicidade, verdadeiro apanágio da segurança das decisões. A mesma crítica serve para o extremo da interpretação concretista, ou seja, pode-se tornar igualmente arma de manobra dos detentores do poder de decidir, haja vista que debaixo da capa de justiça há espaço para todo tipo de decisão. Se um cidadão estudado pode muitas vezes cair na malha dos formadores de opinião e da cultura de seu tempo, o que se dirá de um cidadão sem instrução.

Quanto ao estudo dos elementos do princípio da proporcionalidade, importa salientar que a doutrina pátria os reconhece, mas muitas vezes são ignorados pelo STF, que, quando muito, os cita em suas decisões, sem, no entanto, desenvolver corretamente a relação entre eles e sua forma de aplicação. O que, a nosso ver, fere de morte a previsão constitucional (art. 93, IX) garantidora de sentença fundamentada.

Ainda, a nosso ver, a ideia de sopesamento não oferece nenhum critério objetivo. Trata-se no fundo de um ato de escolha do julgador. Ato 
de escolha carregado de convicções pessoais e valores acerca de qual direito seja mais importante, muitas destas convicções e valores fogem ao domínio do ser humano por mais que se devote a um meticuloso raciocínio. Portanto, escolher é poder. O poder se exerce e é sentido pelos viventes. Não pode de todo ser demonstrado pela ciência, no muito, argumentado, jamais de todo controlado.

Resta, enfim, a esperança no bom senso e na ética, se é que estas também não estão condicionadas. 


\section{BIBLIOGRAFIA}

ALEXY, Robert. Teoria da norma jurídica. São Paulo: Martins Fontes, 2010.

ARISTÓTELES; REALI, Giovanni. Metafísica. $2^{\mathrm{a}}$ ed.. São Paulo: Loyola, 2005. 1v. 341 p.

REALI, Giovanni. Metafísica. $2^{\mathrm{a}}$ ed.. São Paulo: Loyola, 2005. 1v. 695 p.

. REALI, Giovanni. Metafísica. $2^{\mathrm{a}}$ ed.. São Paulo: Loyola, 2005. 1v. 753 p.

Tópicos. São Paulo: Abril Cultural, 1973. 147 p.

ÁVILA, Humberto. Teoria dos Princípios: da definição à aplicação dos princípios jurídicos. $10^{\mathrm{a}}$ ed. São Paulo: Malheiros, 2009. 195 p.

BACON, Francis, Novum organum. São Paulo: Abril Cultural, 1973. 226 p.

BOBBIO, Norberto. O positivismo Jurídico: Lições de filosofia do direito. São Paulo: Ícone, 2006. 239 p.

BONAVIDES, Paulo. Curso de Direito Constitucional, 20ª ed.. São Paulo: Malheiros, 2007. 809 p.

CASTRO, Carlos Roberto Siqueira. O devido processo legal e os princípios da razoabilidade e da proporcionalidade. $4^{\mathrm{a}}$ ed.. Rio de janeiro: Forense, 2006. $450 \mathrm{p}$.

COMTE, Augusto. Curso de filosofia positiva. São Paulo: Abril Cultural, 1978. $36 \mathrm{p}$.

DWORKIN, Ronald. Levando os direitos a sério. $3^{\mathrm{a}}$ ed. São Paulo: Martins Fontes, 2010. 568 p. 
FERRAZ JUNIOR, Tércio Sampaio. Introdução ao Estudo do Direito: técnica, decisão, dominação. $4^{\mathrm{a}}$ ed.. São Paulo: 2003. 370 p.

HÄBERLE, Peter. Hermenêutica Constitucional. Porto Alegre: Sregio Antonio Fabris Editor, 1997. 55 p.

HART, H. L. A.. O conceito de Direito. São Paulo: Martins Fontes, 2010.

HESSE, Konrad. A força normativa da Constituição. Porto Alegre: Sergio Antonio Fabris Editor, 1991. 34 p.

KUHN, Thomas S.. Structure of scientific revolutions. $2^{\mathrm{a}}$ ed.. Chicago: University of Chicago Press, 1970. 210 p.

LUHMANN, Niklas. Sociologia do direito I. Rio de Janeiro: Tempo Brasileiro, 1983. 252 p. . Sociologia do direito II. Rio de Janeiro: Tempo Brasileiro, 1983. 212 p.

MÜLLER, Friedrich. Teoria estruturante do Direito. $2^{\mathrm{a}}$ ed. São Paulo: Revista dos Tribunais, 2009. V. 1. 311 p.

NEVES, Marcelo. A constitucionalização simbólica. São Paulo: Editora Acadêmica, 1994. 263 p.

PASCAL, Blaise. Pensamentos. São Paulo: Abril Cultural, 1973. 241 p.

POPPER, Karl R.. Lógica da investigação científica. São Paulo: Abril Cultural, 1975. $121 \mathrm{p}$.

REBOUL, Olivier. Introdução à retórica. São Paulo: Martins Fontes, 1998. $253 \mathrm{p}$.

SILVA, Luís Virgílio Afonso da. "O proporcional e o razoável". Revista dos Tribunais. V. 798, p. 23-50, abril de 2002. 


\section{GLOSSÁRIO}

Abridgements- Consolidações

Bill of Attainder- é uma expressão empregada no direito dos Estados Unidos da América para designar ato legislativo que importa considerar alguém culpado pela prática de crime sem a precedência de um processo e julgamento regular em que lhe seja assegurada ampla defesa.

Bill of Rights - Petição de Direitos; Declaração de Direitos

Check and Balance- Verificar e ponderar

Common Law- Lei comum

Digest- Digesto

Due Process of Law- Devido processo legal

Final Enforcing Power- Poder final de execução

Founding Fathers- Pais fundadores

Geist- no sentido de espírito e cultura de um povo

Judicial review - Revisão judicial

Law of the land- Lei da terra

Leading case- Caso paradigma; principal caso

Notice and hearing- Notificação e oitiva

Paramount Law- Lei superior

Per legem terrae- Por lei da terra

Police power- Poder de polícia

New Deal- Novo acordo

Reports- Relatórios

Retained by the people- guardados pelo povo (tradição;costumes)

Rule of law - Regra de direito; conceito de legalidade

Standard- padrão; modelo

Statute of Westminter of the Liberties of London- Estatuto de Westminster das liberdades de Londres

Substantive due process- Devido processo substantivo

Yankees- ianques; norte- americanos. 
Modus - modo

Inter partes - Entre as partes 